Originalveröffentlichung in: Christian Frevel, Christophe Nihan (Hg.), Purity and the forming of religious traditions in the ancient Mediterranean world and ancient judaism (Dynamics in the history of religion 3), Leiden ; Boston 2013, S. $115-158$

\title{
CONCEPTIONS OF PURITY IN EGYPTIAN RELIGION
}

\author{
Joachim Friedrich Quack
}

\section{INTRODUCTION}

To say that purity played a major role in Ancient Egyptian culture is hardly more than a triviality. Nevertheless it must be added that detailed research on what precisely purity in Ancient Egypt means ${ }^{1}$ has not yet reached the levels already seen for other cultures, particularly in terms of, e.g., Parker's classical study Miasma or the global analytical approach of Mary Douglas in her study Purity and Danger. ${ }^{2}$ Indeed, it is notable how often dictionary articles are used as the main references, in the absence of substantial, comprehensive surveys. ${ }^{3}$ The problem is by no means a lack of sources, but evidently the opposite. It almost seems that one is threatened with drowning in the vast sea of relevant texts and images. The present contribution cannot give a complete overview, but I want to highlight at least some elements that are of special importance.

There are many sources, but very few are substantial, normative and explicit at the same time. Basic rules, such as the ones exposed in the Old Testament, especially in the book of Leviticus, ${ }^{4}$ are difficult to findalthough I will show, in the course of my analysis, that they did exist and that there are indeed still fragments of them preserved. But exploration of these texts is currently in a very preliminary state, so that we are still forced to reconstruct the core system of Ancient Egyptian purity concepts according to the isolated traces that it has left here and there.

\footnotetext{
1 See especially the monograph of Altenmüller-Kesting, "Reinigungsriten"; still important are older surveys by Blackman, "Sacramental Ideas"; Blackman, "Some Notes"; Blackman, "House of the Morning". Gee, "Requirements" offers some general introductory remarks regarding purification in Egypt, but concentrates primarily on the negative confessions of the Book of Death, Chapter 125 .

2 Parker, Miasma; Douglas, Purity.

3 As, e.g., Blackman, "Purification (Egyptian)"; Meeks, "Pureté et purification"; Grieshammer, "Reinheit", 212-13.

${ }^{4}$ See Douglas, Leviticus.
} 


\section{Purity AND the Temple}

\subsection{Purity in the Egyptian Rituals for Deities}

A temple ritual in Egypt is normally a very complex matter, comprising several different acts. Certain basic structures allow the modern researcher to discern a kind of grammar of the Egyptian ritual.

In the sequence of actions, one typical and important position for purification scenes is at the beginning of a ritual. As a first example, we may examine the so-called "Daily Temple Ritual", which is primarily a ritual for the morning purification and clothing of a cult statue. ${ }^{5}$ Even the first act, which opens the ritual according to P. Berlin 3055 and is labeled quite neutrally "striking fire", turns out, according to the evidence of its closing formula, to be a scene more specifically concerned with purity. This is true of almost all introductory scenes. In the version attested in P. Berlin 3055 , scenes 1, 2, 3, 5, 7 and 8 have the typical closing formula of purification scenes; later scenes contain only a few examples of this formula. The purification scenes appear concentrated again at the end of the text, after the clothing of the statue. To evaluate this structure, we must keep in mind that the ritual does not contain a substantial meal, unless this is to be understood in the very last scene ${ }^{6}$ - but it is conceivable that a food ritual followed it in the sequence of the daily cult.

In the late papyri from Tebtynis, the typical closing formula of purification scenes in this section is even more dominant, including a number of scenes at the beginning of the text that are missing in older manuscriptsthe final part of the ritual is not yet attested in these fragmentary papyri. Among them, there is at least one spell that can be recognized as a direct parallel to the ritual for purification of the king mentioned below. ${ }^{7}$

The structure of the so-called "Ritual of Amenophis" likewise seems instructive to me. This is an offering ritual attested several times in more or less detailed versions from the New Kingdom onward. ${ }^{8}$ Purification scenes appear, firstly, at the beginning of the text, where the reconstruc-

5 The old edition by Moret, Rituel, is not yet completely replaced. The first part of the ritual has been restudied by Guglielmi and Buroh, "Eingangssprüche"; important new manuscripts are edited by Osing and Rosati, Papiri geroglifici e ieratici, 101-28, pl. 14-16. Overall remarks in Lorton, "Theology", 131-45.

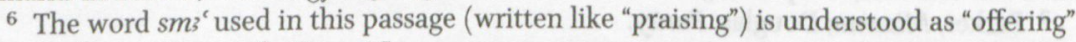
in the edition Hieratische Papyri I, 2.

7 Guermeur, "Nouvel exemplaire".

${ }^{8}$ See the survey by Tacke, "Opferritual". 
tion of the transmitted fragmentary text still faces certain difficulties. ${ }^{9}$ Afterward, we find them when the food offerings are being prepared and served ${ }^{10}$ and, finally, also as a burning of incense and libation to Re, prior to the reversion of offerings on the altar of the king. ${ }^{11}$

As another example, we may cite the Ritual of Opening the Mouth, which in the temple sphere is mainly a ritual for the consecration of divine statues. ${ }^{12}$ There we find purification scenes, both those with water as well as those with incense (scenes 1-7), concentrated at the beginning. In subsequent parts of the ritual, even though there are still numerous incense acts, their purificatory aspect is stressed less. A noticeable use of water for purifications is discernible at one specific point, directly before the great food offering. We have, on the one hand, spell $63 \mathrm{~A}$, a purification in the House of the Morning, which in the actual attestations always stands directly before the king's offerings in the court of the sun-god (scene $65 \mathrm{C}$ ). On the other hand, the purification-focused scenes 67 (purification of the god's offerings with libation and incense) and 69A and B (accomplishing the ordinary glorification, pouring water on the altar) come directly before the great offering list in scene $69 \mathrm{C}$. Similarly, a specific formula for purifying the offering meal is attested in several temples of the GrecoRoman period..$^{13}$

Thus a basic structure can be recognized: purification scenes are usually placed at the beginning of a ritual, in order to define the place, persons and objects involved as being pure. Within a ritual, purification plays a particular role where the serving of the food-offering is concernedcasually said, it may be compared to today's fast-food restaurants, where the waiter cleans the table when a new guest arrives. Such daily, routine aspects should not be considered irrelevant.

A peculiar feature of the wording of purity formulae requires explanation. The typical closing phrase of such a spell is the final htp-çi-nsw iw=i w'b.kw "a king's offering; I am pure". The expression "a king's offering" is otherwise quite usual in an offering ritual, but it always introduces material objects, especially food but also cutlery, ointment or clothing. From this feature we can probably conclude that purity has a quasi-material quality

9 Scenes 10 and $n$ (libation and fumigation), in particular, are important.

10 Scenes 24-29 in Tacke, "Opferritual".

II Scenes 42 and 43 in Tacke, "Opferritual".

12 Otto, Mundöffnungsritual; Quack, "Fragmente". For the question of the scene sequence, see Quack, "Prätext".

13 Goyon, "Formule solennelle". 
and that the king officially permits the performance and acknowledges the efficacy of purification as well as the giving of food and endowment as royal favors. The question of purity in proximity to the king, which I will discuss below, may also be connected with that point.

The typical combination in actual practice is the pouring of water and the fumigation with incense. Alongside that, there is a purification with natron, which of course is normally part of the water pouring, as natron is dissolved in water. These are the usual purification substances, and all others must be classified as unusual. At times we must also take into account that purification with, e.g., lapis lazuli (e.g., Dendara VIII 92, 2) indicates only purification with water poured out of a jar made of this substance. ${ }^{14}$

As a special case regarding terminology, in particular for purifying substances, it should be noted that the verb sw'b "to purify" is sometimes used in the sense "to decorate" (WB IV, 67, 2-3). Especially noticeable is the postscript to the Book of the Dead, chapters $30 \mathrm{~B}+64$ and 140 , which are recited over amulets (a scarab and an Udjat-eye, respectively) said to be made of precious stones and literally "purified with gold", ${ }^{15}$ meaning in concrete terms, as archaeological finds show, ${ }^{16}$ a setting in gold. In any case, this expression demonstrates that Egyptians classified gold as a substance with purifying power. This should be understood in light of the fact that gold was also considered to be the flesh of the gods. ${ }^{17}$

\subsection{Purity as Condition for Access to the Temple}

The Egyptian temple is a system with zones of increasingly limited access. This is a matter not only of purity as such but of authorized access only for certain classes of priests. Here the ontological question must be asked: do consecrations linked to a specific higher class of priests imply a possible degree of purity that would not be achievable without these consecrations, that is, simply by keeping purification regulations as such?

\footnotetext{
14 Compare the figure in Dendara VIII, pl. DCCLXXIX, where the priest in question holds a sistrum and a jar in his hands.

${ }^{15}$ For purification with gold in the Greek area, see Parker, Miasma, 228.

16 See e.g. Quirke, "Heart Scarabs".

17 Compare Schott, Kanais, $150 ; 169-70$. No in-depth treatment appears in the section about gold in Aufrère, Univers minéral, 353-406.
} 
The access rules are laid out most clearly in the Book of the Temple; ${ }^{18}$ therefore, I would like to present the most important passages from it. The architectural section, which gives a description of the temple from the inner- to the outermost parts, is especially relevant. The first of the relevant entries is unfortunately in a badly preserved description of the interior part of the temple building, perhaps in a section where the sanctuary and then the central halls were first mentioned. There, it is said: "[No] man [enters] them, apart from the prophets [of this] house(?)". The next note is much better preserved. In it, the pronaos is defined as the last of the interior rooms, where space is also provided for the gatekeepers. Here we are told: "Now the whole temple is marked off with buildings in its square. No person is admitted into it, apart from those who serve as high-ranking priests for the gods' rituals".

Beyond the rules for priests, the building section of the Book of the Temple also gives information on buildings in the open outer court, which is marked off by a pylon; here we find, among other structures, "The 'house of the morning', in order to perform the purification of pharaoh in [it] when he enters the temple". The next court, located further outside, is called the "court of the assembly", which, of course, implies more general access. Nevertheless it should be noted that "assembly" ( $m s^{\check{*}}$ ) can also be the name of a group performing the common cultic practice, suggesting that perhaps only men with institutional affiliation with the temple are envisaged. Here as well it is said, "A room is in it in order to perform the purifying of the king when he enters the temple". The third court is defined as the location of a certain group, unfortunately lost in a break but obviously not included in the word "assembly". Either women or non-priest inhabitants of the city are possibilities.

Special strict regulations for access are stipulated for the Osirian part of the temple. Only a few ritual specialists had access here; if someone unauthorized was caught, he would be treated as someone who had blasphemed the king, namely, he would be executed and placed on the fire altar. We can debate whether the decisive matter is just purity or whether there are other factors at play. Osiris is the endangered god, and there is also a high risk of abuse with regard to the figurines deposited in Osirian areas, which have considerable power as they are a god's substance.

18 I am currently working on this comprehensive handbook; see, as preliminary reports, especially Quack, "Buch vom Tempel”; Quack, "Manuel du Temple”; Quack, "Organiser le culte"; Quack, "Les normes pour Osiris". 
The most substantial currently published source concerning rules of purity and access to temples is an inscription in the temple of Esna. There, a long digression on the question of who has access under which conditions and where is intercalated into a description of the sequence of a temple ritual.

Everybody, moreover, has to be pure from a woman in a purification (period) of one day, they shall purify them and moisten their clothes. Do not let anybody enter who suffers from god's anger or leprosy! Their position is in the surroundings of the temple. One should open the jar of this ... to the left and the right of the dromos by everybody who is pure from a woman in a purification (period) of nine days. Whoever opens the jar within the (perimeter of) the water which is around his temple, they shall sit to the right and to the left, whereas it is not allowed that they lie down.

Performing of jubilation cries (?) in its interior by everybody. No person shall enter with the fur of a sheep around him. No craftsperson shall enter into it. The position of the city-dwellers is the wall of the temple, they should not enter onto the quay. Performing the offering on the altar of this honorable god by the prophets, the priests and all service staff of the temple. Whoever wears a hairstyle of grief does not enter into this temple! Shaving, nail clipping and combing is what (justifies) entering into it. All fine linen as a dress is what (justifies) entering into it. Natron water is what (justifies) settling down in it. As for all having allowance to enter it, they should be pure from a woman in a purification (period) of nine days and should not have eaten any taboo in a purification (period) of four days. As for anybody wishing to enter the temple or who has to do some work there, he shall have shaved his limbs and clipped his nails, and let him pray to the god at the dromos in the position of the city-dwellers while the service staff of the temple stands beside him and says: 'Be pure from a woman in a purification (period) of nine days and of each taboo in a purification (period) of four days'. If he acts this way, he can enter the temple at the door which is at the side of the pylon tower, after purifying himself as well as his clothes in the lake. Do not let any Asiatic/shepherd enter the temple, be he a small or a large one! Do not let any woman get close to all his surrounding within an area of 200 arourae. An island is at each side, so that you will not overstep it for 15 measure cords (of one hundred cubits) in the south and the north, 15 in the west and east. Their position is the causeway, it should not be overstepped to the north to the Golden one of $\mathrm{Ai}$, to the south, west and east to the marsh of Khenit. Be careful about it! Beware of it! The king is in his good state, the whole country is free from calamity. Who is insistent in that will have worth; woe betide the one who commits an outrage against this! (Esna 197, 16-21) $)^{19}$

19 Sauneron, Les fêtes religieuses d'Esna, 340-49; Leitz, Tempelinschriften, 77-81. 
The varying terms of abstinence and of purification from different pollutions find a remarkable echo in a Greek inscription from Megalopolis in which such criteria are defined, in that case for access to the temple of Isis and of Serapis. ${ }^{20}$

In a hieroglyphic inscription from Philae, at the door of the northeast corner of the court between the first and second pylons, regulations for access are expressed as an address to the doorkeepers. The announcement states, among other things, what kind of plants and animals a person is not allowed to eat if he wishes to be able to enter the temple. ${ }^{21}$

$\mathrm{O}$ door keepers who are in this temple,

Powerful ones of the throne who are in their monthly service,

Those offices which will be in the hall,

Carrying out their duties without ceasing,

They are those who will be pure in the days,

Who will eat from the pure place of preparing foodstuff!

Those are the taboos, which you should not eat,

Which are not allowed to come near to the inner part of the temple:

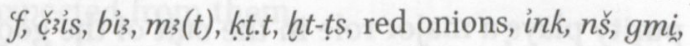

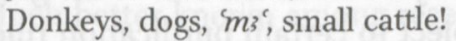

Do not be indulgent with big and small

Concerning the state of this temple!

If something bad comes about to happen against this temple,

Then it happens against Upper and Lower Egypt,

Then each god will get angry against his place.

One should not overstep the way of one's house,

Without decaying, without fading away for eternity.

O door keepers of this temple,

Hourly priests of the temple doing their duty!

You should not let any person from the outside enter into the sanctua[ry]!, Who do not know [...],

Who fight against that which comes out of the mouth of the prophet,

Likewise any overseer.

Concerning the one who wants to enter, they should come out in front of you,

So that no-one from the outside is with him.

This means all things which will enter in front of you!

Beware of things in contamination (sst),

So that nobody will enter these halls,

20 Bricault, Recueil, 42-43; similar, but in a more general way, also in an inscription from Eleusis, page 29-30.

${ }^{21}$ Junker, "Vorschriften"; Aufrère, "Végétaux interdits". 
Except in order to fulfill his service, unseen and unheard(?)!22 Beware of possessions from theft!

(Even if) nobody will be caught due to his (other) misdoing, He will still be brought (to court) because of a case of the temple!

In order to grasp...

The staff of treasury which is in the temple

Is informed about what happens to him.

If there happens anything good for the temple,

Then the god at his place is a peaceful god,

And he puts this country into its correct state,

He embellishes the fate in the temple.

In any case, an image of the king who solemnly says "everything that enters the temple should be pure, pure" is an often-attested element of temple decoration, precisely in the areas of entry and passageways.

\section{Purity for the Priest}

If, as mentioned above, purity plays a major role in the cult of the gods, it is obvious that the priest would be subject to certain purification rules. ${ }^{23}$ Indeed this can plainly be shown by the fact that the normal word for priest, namely $w^{c} b$, is a derivation of the root $w^{c} b$ "to be pure"; it is, by the way, still used as оүннв for designating Christian priests in the Coptic language.

The purification rules for priests are best documented in instances when they were not kept. In the so-called Elephantine scandal, a denunciation dating to the 20 th dynasty against a priest who is accused of several offenses, it is also written:

Indictment that he walked into the cella of the fortress while it was (only) six days of drinking of natron which he had done, and the scribe of the treasury Montherchepsch imposed an oath upon this prophet of Chnum with the words 'I won't let him enter to this god until he completes his days of drinking natron', and he did not listen to him and entered to the god while he still had (to complete) four days of drinking natron. (RAD 75, 4-8)

This shows the obligation of drinking natron for ten days in order to have access to the god's statue in a state of cultic purity.

22 The text seems to be transmitted in quite a bad way; Junker's "which no one else should see" is impossible, as $n b$ can never be constructed as a substantive. I assume the common formula $n$ m33 $n$ sç̌m.

${ }^{23}$ See with a special focus Musso and Pettacchi, "Sexual Taboos". 
The ostracon Narmouthis 109, from the later Roman period, also mentions a priest who was still in a state of incomplete purification when a certain document was brought; he did not become pure until the next day. ${ }^{24}$ Unfortunately the exact duration of the period of purification cannot be determined, but a fixed term is nevertheless certain.

In principle, certain Roman-period hieratic papyrus fragments in which a handbook with rules for temple services is preserved would be of major relevance. This text, which is not the Book of the Temple itself but which bears some similarity to it, is transmitted in P. Carlsberg $386+$ P. Berlin 14938 , and possibly also in Greek translation in P. Washington University + P. Oslo 2 vs. ${ }^{25}$ It is a collection of laws and regulations relevant for the temple and some priestly groups, in which elaborate norms are fixed for the priests, especially those of high rank. Only certain clothing is allowed for access into a temple, as are only certain kinds of food for the prophet. As soon as it becomes possible to sort the fragments into more complete sections, substantial progress in understanding Egyptian cultic purity can be expected from them.

Much better known among researchers are hieroglyphic temple-access texts. ${ }^{26}$ They appear quite typically in passageway settings, i.e., mostly as inscriptions on doorjambs, where they indicate the rules governing passage into an area of more restricted access, for example, an important route to the offering altar. Different stylizations are attested, such as admonitory speeches concerning what the entering priests had to avoid. In addition to the interdiction of impurity, different kinds of moral misconduct are also highlighted. Such forms are known, e.g., from the temples of Edfu and Kom Ombo:

O prophets, god's fathers, ritual leaders, god's purifiers, high-ranking priests, all those Having access who enter to the god, ${ }^{27}$ all governors in their monthly service, War-Priests, ${ }^{28}$ 'In-the-earth'-priests in the house of the forms, who have access to the Temple in great Purity, in order to prepare the ointment of the first feast, those who purify themselves for Performing the god's rituals every day, those who purify Themselves at the first day, in order to let the god appear at his time of his navigation feasts!

${ }^{24}$ Menchetti, Ostraka, 49-50.

25 See Quack, "Buch vom Tempel", 18-19; Quack, "Translating the Realities".

26 Gutbub, Textes fondamentaux, 144-84; Leitz, Tempelinschriften, 36-42; comparison with biblical texts in Weinfeld, "Instructions". For later traditions, see Grieshammer, "Unschuldserklärungen".

27 The Edfu version adds here "all lector-priests".

${ }^{28}$ From here onwards, only the titles at Kom Ombo are given. 
Do not introduce in trespassing!

Do not enter in a state of grime $(s 3 t)$ !

Do not tell lies in his house!

Do not snatch through calumny!

Do not accept any list(?)

In being partisan against the small for the great!

Do not add to the weight and to the measuring rope,

And you shall not detract from them!

Do not change arbitrarily in the grain measure!

Do not hurt the bushel of the eye of Re! ${ }^{29}$

Do not reveal what you have seen in privacy

Of all secrets of the gods and goddesses! ${ }^{30}$

Do not stretch out your arm for possession in his temple!

Do not take any liberty to steal his possession!

Beware lest a fool says in is heart:

'One lives by the food of the gods'!

One designates as 'food' what is coming from the offering altar in circulation, After the god has satisfied himself with it.

He sails in heaven; he crosses the celestial vault, ${ }^{31}$

While his eyes lie on his possessions at their location.

Do not do anything bad against the servant of his house!

He loves his servants very much!

Do not have any sexual intercourse under pressure!

Do not impose any condemnation!

Do not exert any violence against the people in the fields and in the city,

Because they came out of his eyes,

They originated from him!

His heart is very sad about injustice in punishing,

If there is no witness(?). ${ }^{32}$

Do not run with your soles,

Do not be short-tempered in a moment!

Do not give your mouth free run in a discussion!

Do not react with loud voice against the voice of somebody else!

Do not impose any oath over something!

Do not prefer the lies against the truth in a complaint!

Beware that you are not (too) big when passing your service times(?)!

There is none who complains against him

Who is free of being punished for something.

29 The grain measure is understood as the eye of Re in Egypt; see recently Quack, review of Lippert, Demotisches juristisches Lehrbuch, 173 with references.

30 Variant in Edfu: "at all secrets in the sanctuary".

31 Variant in Edfu: "the underworld".

32 This whole paragraph is only attested at Edfu. 
Do not sing in his house in the inner part of the temple at the location of the women!

Do not do anything at a place where it should not be done,

So that there is not a party taking place in his house,

But only at the place in front of which it is allowed to sing

By the entity(?) of the staff(?)!

Do not open the jar in the inner part of the temple,

So that you will not be drunk from it! ${ }^{33}$

Do not anything according to your heart,

But you should look at the old writings!

Pass the directions of the temple in your hands

As an instruction for your children!" (Kom Ombo, text 878 with parallel in Edfu III, $360,12-362,4)^{34}$

Another stylization is that the officiant-on an ideal level the king in this role - explains to the doorkeepers - on an ideal level the gods in this role- that he did not do certain condemnable things.

O Gods in [...], in [Upper] and Lower Egypt,

Door-keepers of the big gateway,

Great Gods being secret of place in Edfu,

Who segregate the god in his chapel,

Who strike on his offering altar, ${ }^{35}$

Who receive offering food at his side in the hall of the ennead! ${ }^{36}$

Make way for me, so that I enter with you!

I am one of you,

I am Shu, the oldest of his father,

The high-ranking priest of him with spotted feathering,

Priest $[\ldots]$

$\mathrm{O}$ great gods $[\ldots]$ of $[\ldots]$

You should [not deter] me from the way of the god,

My legs shall not be opposed,

I will not be kept away from the enclosure of Ta-Wer,

That I will give orders about the god's substance,

That I give offerings to the one who created them,

That I give bread to Horus [...]

$[\ldots]$

Not $[\ldots]$ on the way of god.

33 This paragraph is only attested in Edfu.

${ }^{34}$ Alliot, Culte d'Horus, 184-186; Fairman, "Worship", 201; Gutbub, Textes fondamentaux, 144-84; Kurth, Treffpunkt der Götter, 148-49.

35 So the orthography of the inscription; the phraseology would be more in favor of "who hit with his scepter".

36 In my opinion, against the translation by Alliot, only participles, not imperatives, can be read here. 
I have not been partisan in the judgment, I have not allied with the strong one, I have not convicted the weak one, I have not led things in a violent manner, I have not decreased the parts of the eye of $[\operatorname{Re}(?)],{ }^{37}$

I have not [...] with the hand scale, I have not committed an outrage against the bushel of the god's eye! Council $^{38}$ of the great god in this house, Great ones who are sitting on the mat, Messengers who [...] in a hurry!

Behold, I have come to you, in order to do the truth for the master of the truth,

To satisfy the Udjat-eye for his master.

I am Shu, who is furnishing his offering-table prosperously,

So that I pile up his offerings.

Tefnut is united with me, ${ }^{39}$

That I adore Behedet ${ }^{40}$ at his feasts,

That I kiss the earth because of the greatness of his esteem,

That I unite life with his divine power.

I am a priest, I am pure! (Edfu III, $78,10-79,4)^{41}$

O Door-keepers, great Gods, masters of the flame, with long rays,

Who open the door-wings of heaven and illuminate the two countries,

Guardians [...] Upper and Lower Egypt,

Who stand and sit at the right and at the left,

Kings of Upper and lower Egypt of the south and the north,

Venerable ones of the gods!

I have come to you, great gods,

After Horus has purified me,

After Thot has perfumed me with incense.

Make way for me so that I can pass!

I have come on the way of the god,

I have entered praised and have emerged loved,

There are no male and female adversaries on my path.

You cannot detain me, you cannot restrain me.

The ram is my witness, the ram of the rams is my witness.

I am Thot, the Great, the deputy of Re.

I have come in order to accomplish rituals,

The two male baboons are at my right,

${ }^{37}$ This refers to grain measures, see above note 29 .

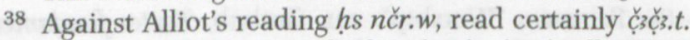

39 The sister of Shu. I read Tfn.t shn.ti $r$-hn'si. Alliot ignores the sign of the lion-headed goddess and creates an impossible syntactic structure.

40 The cultic name of the city Edfu.

${ }^{41}$ Edited by Alliot, Culte d'Horus, 142-43. 
The two female baboons are at my left.

$\mathrm{O}$ those who live from $[. .$.$] ,$

Who endow the altars with food!

I do not diminish the offering bread,

I do not do painful things.

I have not made any dirt.

Horus is my purity.

My hands are Horus,

My arms are Thot,

I have brought the Udjat-eye to his master,

I have put Maat in her place.

I am a prophet,

It is the king who has sent me to see the god.

A king's offering, I am pure. (Edfou III, 83, 2-11) 42

The fact that Egyptian priests underwent a purification with water in connection with access to the sanctuary is well documented in temple reliefs, e.g., at the bark sanctuary ("Chapelle Rouge") of Hatschepsut from the 18th dynasty. ${ }^{43}$

The neo-platonic philosopher Porphyrios has transmitted a long excerpt from the treatise of the Egyptian priest Chairemon in his book about abstinence from carnal food, in which the ideal and ascetic life of the Egyptian priests is described (De abstinentia IV 6-8). ${ }^{44}$ With regard to the food, for example, some of the priests would abstain from any kind of food deriving from a living creature, and all of them abstained from animals with cloven hoof, from meat-eating birds, and from a large number of special cases, such as female cows.

At this point it is relevant to pinpoint more precisely the chronological development. The typical pictures of shaven-headed priests appear only in the course of the New Kingdom; for example, at the sanctuary of Hatschepsut they are still shown with wigs. In contrast, from the Ramesside Period onward, depictions of priests with hairless heads become common. This could be a sign that purity restrictions had become stricter at this time, or at least that more value was attached to demonstrating them visibly to the outside. Still, it should be noted that there are already occasional depictions of people with shaven heads in the Late Middle Kingdom, even though their titles do not clearly link them to priesthood. ${ }^{45}$ By far the

\footnotetext{
42 Edited by Alliot, Culte d'Horus, 144-45.

43 See Burgos and Larché, Chapelle Rouge, 212 (left) and 216.

44 Horst, Chaeremon, 16-23; Patillon, Segonds and Brisson, Porphyre, 9-13.

45 See e.g. Habachi, Heqaib, pl. 162-63 and 166-67 (a warden of the chamber and a retainer); Wildung, Ägypten 2000 v. Chr., 137 and 152 (a vizier and a beer brewer).
} 
most explicit ones among the textual sources are very late texts, mostly from the Graeco-Roman period.

\section{Purity for the King and the Palace}

The above-mentioned places for the purification of the king in the temple lead us to the next complex. The person of the king was strongly connected to purity concerns in Egypt. ${ }^{46}$ Indeed, there exists a detailed royal ritual focused on purification rites. In full form it is transmitted in at least four different papyri, of which only one is published. ${ }^{47}$ All of these manuscripts date to Roman times, when in Egypt itself there was no longer a pharaoh who could have used them, raising the question of the extent to which they were really used, perhaps adapted for priests. More substantial sections, obviously from the same ritual, are already to be found in some scenes of temples in Ptolemaic times, especially in Edfu. ${ }^{48} \mathrm{~A}$ single scene already has a parallel in a spell that has been incorporated into a relatively unusual Book of the Dead in the New Kingdom (P. Busca). ${ }^{49}$ Another has nearly verbatim parallels in a royal ritual conveyed in a papyrus from approximately the 26 th dynasty (or at most the 27 th dynasty), as well as a shortened and adapted version for a goddess in a scene of the temple of Dendera (Dendara IV 249, 16-17). ${ }^{50}$ Although I am not able to treat the history of the tradition in all its complexity, I would like to suggest that this is presumably a substantial and long-standing ritual. Indeed, this text could easily be the longest and most explicit text of all concerning purification and its attainment in a ritual in Egypt. Therefore it should be presented in as full a form as possible:

First spell

Poorly preserved

Second spell

Poorly preserved

46 Smith, "Kingship".

47 Schott, Reinigung Pharaos; for the Tebtynis manuscripts and for global interpretation, see Quack, "Königsweihe", 97-99.

48 Noted in Schott, Reinigung Pharaos, 6o-64.

49 Crevatin, Libro dei morti, 50-51.

50 Goyon, Confirmation, 53 and 84. 
Third spell (restored from parallels):

Spell for the water

O Water, may you abolish all bad defilement of the pharaoh,

$\mathrm{O}$ inundation, may you wash off his errant demons.

May you wash the face of Horus,

May you rub the face of Seth,

May you wash the face of Neith,

May you rub the face of her spinners,

May you yourself rub the face of the pharaoh

As the face of the king when he bedecks his crown!

Loosened are the bands of the pharaoh through Horus,

Opened are his bands through Seth.

His purity is the purity of his god.

He shall not fall on some evil obstacle!

A king's offering, Pharaoh is pure.

\section{Fourth spell}

Spell for water, speaking words [by...]

[O you Gods...,

Come] that you [erase] all evil in him.

Any taboo he did, $[\ldots]$ at the lake!

His mouth...

His purity is the purity of Horus - and reverse,

His purity is the purity] of Seth-and reverse,

His purity is the purity of Dun-Awi-and reverse,

His purity is the purity of the Djed-pillar-[and reverse,

...] Pharaoh his purity.

A king's offering; Pharaoh is pure.

Fifth spell

Poorly preserved

Sixth spell (restored from parallels)

..., speaking words by $[\ldots]$ the great council which is in $[\ldots]$.

Purification of the mouth of pharaoh with [...]

$[\ldots]$ whose amulet is made out of shiny stone,

Who settles on the gates of the horizon,

Who is without stain $[\ldots]$

$[\ldots]$, who follows Re at the place $[. .$.

Who lives without wounds of his.

The purity of the pharaoh is the purity of this female vulture [...]

$[\ldots]$ that means to save him from ... [in] any council...

$[\ldots]$

Seventh spell

Poorly preserved 


\section{Eighth spell}

Another spell for purification, speaking words:

Pharaoh has [purified himself] with the great waters

Which come forth from Elephantine, which originate from the [primeval ocean].

He has [purified] himself with the eye of Horus,

He has purified himself with its own substance.

Isis has purified him as she has purified her son Horus in Chemmis.

$[\mathrm{He}]$ is the one, prestigious in his dignity (?) in truth,

He is Thot who purified himself with his own substance,

[as] Re purified himself with his own substance.

He has perfumed himself with incense, natron is adhering to his limbs.

Pharaoh is Horus in Chemmis.

To be spoken on four pellets of incense, four pellets of natron, putting them into water in a new bowl, to put a falcon of wax into it and some [...] that means $[\ldots]$.

Ninth spell (parallel in P.Busca and for a part also in the "gold amulet" text) Another spell for purification

A papyrus amulet of ore of the goddess is for pharaoh,

Abolished is [all evil] from his head (?).

The eye of Horus rests in its place,

Secured for pharaoh as protection of his head.

[Pharaoh did come] from the grove,

He has swallowed its fruits.

He has received his head, he has united his bones,

He has washed himself; abolished is what (evil) was adhering to him.

His purity is the one of Min from Coptos,

As he counted his eyes as double feather,

And his voice was justified through it.

His purity is the purity of a little calf at its milk,

The day its mother gave birth to it.

His purity is the purity of the way-opener,

As he let his eyes move up to his face, (?) as uraei,

And he set them on his head as Isdes.

Thot purifies the head of the pharaoh, his mouth with water jars,

He has secured it with jars of water,

He has purified it with gushing water,

He has perfumed him with incense coming from Punt.

Pharaoh follows Horus so that he lives,

He follows Atum and endures.

Horus has protected him, Atum has ascertained him,

Geb has abolished all evil from him,

Horus has abolished from him all evil adhering to him (?).

The arms of Isis are a stronghold for pharaoh against all evil,

It shall not come against him, 
It shall not rise against him in eternity.

He has united with the Horus eye-

Variant: the Horus eye is well-disposed towards him,

It shall not rise up against him!

May you awake in peace,

May the ore awake in peace!

Horus purifies himself with him,

Seth purifies himself with him,

Thot purifies himself with him,

Dun-Awi purifies himself with him,

The Djed-pillar purifies himself with him.

May they abolish with it the evil adhering to themselves!

Pharaoh purifies himself with him,

May he abolish with it the evil adhering to him!

$\mathrm{He}$ enters into it with the cast-off (garment),

He comes out from it with his jaded (garment).

You have dressed what is at his head,

You have clothed what is at his feet,

You have clothed what is at his bottom,

You have clothed what is at his arms,

You have clothed what is in all his dreams,

In that night when he saw himself at this his place.

Pharaoh is purified with this water which came out from Osiris,

He has provided his bones with what belongs to him.

A king's offering; Pharaoh is pure.

Words spoken over a papyrus amulet of ore, put into water, purifying the king with it.

\section{Tenth spell}

Another spell of purification which is done for the king.

Hail to you, you four gods who are in the primeval ocean!

Pharaoh has come to you, arisen in the inundation.

Pharaoh has opened the flood with his wings,

He has opened the cavern with his horns,

He has crossed the islands in the water of Horus.

He has purified himself with his magic,

He settled down(?) at the shore of the primeval ocean,

...the shape of Tatenen.

The impurity ( $b w$ ) of the pharaoh shall be upwards(?),

His evil shall belong to the shore,

What he dislikes shall be in the water,

Swimming...

He has repelled his enemy when he rose in it.

He has thrown down his enemy. 
Pharaoh is Horus in the primeval ocean,

No dead man's spirit has power over him. ${ }^{51}$

The gods are satisfied with the purity of the pharaoh,

When the magical formulae are recited $[\ldots]^{52}$

$[\mathrm{O} \ldots]$, whose glow is a fire,

And his flame a torch ${ }^{53}$ in the eyes of all his enemies among the dead and alive ones, etc.

Pharaoh is pure, he has unified with his Ka in ... of the Kas,

Pharaoh is pure,

As the four gods in the primeval water [are purified and have] unified with their Ka.

Pharaoh knows them and knows their names,

In their manifestation, in their natures, in their shapes, in their limbs. ${ }^{54}$

["Osiris who satisfies Re] with his truth" is the name of the one,

He is pure, purified on his portico(?).

"Tatenen" is the name of the next one,

$\mathrm{He}$ is pure, purified on his elevation.

["The light in] its [perfection"] is the name of the next one,

He is pure, purified on his hill.

"He has taken hold of himself" $" 55$ is the name of the next,

He is pure, purified on his shore.

Pharaoh now is "Osiris who satisfies Re with his truth",

He is pure, purified on his portico(?).

Pharaoh now is "Tatenen",

He is pure, purified on his elevation.

Pharaoh now is "The light in its perfection", 56

He is pure, purified on his hill.

Pharaoh now is "He has taken hold of himself",

He is pure, purified on his shore.

Pharaoh has crossed the things(?) in the primeval ocean,

He has purified himself in the primeval ocean.

Water is on pharaoh,

No dead man's spirit(?) can encroach on him, ${ }^{57}$

51 Compare Quack, Merikare, 89, for the meaning. Schott's mistaken translation "Death has no power over him" has led to the assumption that this is an ontological statement that death developed after creation and therefore had no power over the primeval water and the people in it; this reading has unfortunately also been received in Hornung, Eine und die Vielen, 170 note 119; Assmann, Totenliturgien, 544.

52 In P. Carlsberg $65^{8}$ hft nis.tw sh.w is clear; traces of that are also found in the Berlin papyrus.

53 According to the photograph, read against Schott tkz.w, not t3.w.

54 Addition according to P. Carlsberg 658 .

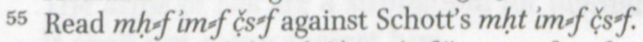

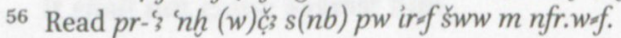

$57 \mathrm{I}$ read $\mathrm{nn} \mathrm{hm}[\mathrm{mwt}] \mathrm{im} \cdot \mathrm{f}$; the determinative of the dying man is still preserved at the beginning of line 3,9 . 
His impurity does not exist.

A king's offering, pharaoh is pure.

To recite upon four figures of the inundation god, in their shape $(b s)$ and their form $\left(\mathrm{km}_{3}\right)$ during $[. .$.$] , liquid of every [. .$.$] in them. To go around$ the king, [every single one...], purify on all limbs(?) of the king. To speak words, to abolish impurity, abolishing of impurity, male and female dead man's spirits, male and female enemies, male and female opponents.

This book has been made by the Lord of All when he purified his limbs(?) after the evil impurity of men, gods, glorified and dead ones.

Eleventh spell

Another spell for purification, words to be spoken.

Pharaoh is Re, arising in the primeval ocean,

[His] purity is [the purity of... in the] water,

With big flame...

Great illuminator when he shows himself in the flood in the morning,

Who abolishes all evil, as he arises in his purity from the flood.

May pharaoh arise in the flood(?)....

... shine... pharaoh...

May he be divine in the earth!

Those who are in the primeval ocean shall not upset him,

... shall not... him...

Here there occurs a break of continuity in the script. A direct sequence is, against Schott, anything but certain. The text begins in the midst of an instruction for action.

[...] together with this statue. Blowing by khenu-sa-priest. One says 'raising of the hands' [...] of the king, right to right, [left to left]. His ointment jars [...], sealed upon real myrrh, to place on the feet of the king to the right and the left $[\ldots]$, to the arms, at the feet. A calf... within this heaven (= baldachin?). Then he shall kiss the calf after the purification [with four jars] of water. [...] To release(?) the bark of Sokar. One says 'Releasing the encircler among the people (?) [. . .... let(?) of Ptah. An amulet of the seneb-plant at his arms and legs, the sinew of a [...] upon his head, anointed with best ointment, his [body] dressed with two loincloths.

Twelfth(?) spell

Nephthys, come and purify pharaoh from all vermin he has killed, be it that he knew it or not, of which a god hated that he killed them! Relinquished is all evil that was adhering to him by magic!

As Re-Harachte was pure with this water which came from Heliopolis at the east side - repelled is all evil from pharaoh.

As Horus the little child was pure in his nest in Chemmis when he arose $[\ldots]$ and killed his enemies. 
As those four goddesses were pure, Neith, Selkis, Isis, Nephthys, as they purified themselves [...] who originated from Atum.

As the winepress god was pure in Edfu when he purified himself from the hind-part of the red fish-repelled is all evil from pharaoh.

As Horus the oldest was pure, the begetting bull who grasped Isis(?) ${ }^{58}[\ldots]$ of the sea.

As the Apis-bull in the Serapeum was pure when he purified himself in the field of rushes when he had received [...] chapel of the crooked one in Akhmim.

As the eyeless one in Letopolis was pure after he had chopped off the heads, blindly $[\ldots]$ of his mother, and she closed his eyes.

As Horus was pure in Pe and Mesen when he wiped off... after he had chopped off the heads [....] of his enemy.

As the wild bull was pure in Buto-repelled is all evil from him, repelled is all evil from the pharaoh.

As Horus the leader of subjects was pure at that very day when for him these four hands have been made, fallen into the water.

And Re pronounced that he was pure by them on the shore of Netjeretrepelled is all evil from him, repelled is all evil from the pharaoh.

As Seth was pure in Tachbeti when he moved out of Tachbeti and came down to Nedit-repelled is all evil, equally.

As Horus the child was pure when he gave orders to the gods-repelled is all evil, equally.

As Horus-Min in Coptos was pure on top of his plantation when he was given his eyes as double feather and was justified, and his face should not lack them-repelled is all evil from him, repelled is all evil from the pharaoh.

As Horus-Min was pure in Coptos when his eyes were given to him, his right and his left one, and they were fixed on his head, and his face should not lack them-repelled is all evil from him, repelled is all evil from the pharaoh.

As the way-opener was pure when he united his eyes at his head as uraeusrepelled is all evil, equally.

Thot, come that you fix for pharaoh his head

With this water which has come forth from Elephantine,

Which removes grime(?) which the lips have devised,

Which the one who beats with magic attests against him.

Pure is Horus, pure is Seth,

Pure is Thot, pure is Dun-Awi,

Pure are these four gods who have come forth around the lake of life.

Pure is pharaoh, repelled is all evil from him through magic

$[\ldots]$ against him, he cut off $[. .$.

58 If the reading is correct, this could allude to a myth according to which Horus violated and raped his mother; see Meeks, Mythes, 269-70. 
Thirteenth(?) spell

$[\ldots]$

Horus has risen in the two chapel-rows of heaven,

He whom the lady of hearts has hidden(?) inside them,

Beautiful is her head with Thot,

The orphan child of lip and curl,

The son who came forth from a male one,

The ibis, ${ }^{59}$ great of magic,

The runner who separated the two gods.

(End of the preserved part of the Berlin manuscript)

From the unpublished part (according to P. Carlsberg 658)

"[Pharaoh has purified himself] with the water jar with which Horus has purified himself,

He has loosened the evil of him to the ground,

He has $[\ldots]$ taken away to the ground.

All male ones who will do anything against pharaoh,

Their bodies, their limbs [...] their [...],

They shall eat feces, while their drink is urine in their places [...],

Their heads shall be in the earth, their feet in heaven.

Those who say anything evil against pharaoh,

Shall be addled (?), ${ }^{60}[\ldots]$ their $[\ldots]$ against them themselves".

The purification of the king is a well-known motif in Egypt. Strangely, though, one of the most ancient known attestations of the motif comes from an "indirect tradition", namely a Middle Syrian cylinder seal (today in Brussels); ${ }^{61}$ in some other seals and impressions, the details of the motif become increasingly less Egyptian in style and iconography. In Egypt itself, there are a few fragmentary cases from the Old and Middle Kingdoms; the earliest known complete attestation, by contrast, is a pectoral from the beginning of the 18 th dynasty. ${ }^{62}$ Afterward, from the New Kingdom until the Greco-Roman period, the motif of the king being purified by two or four gods is quite well attested. ${ }^{63}$ The stylization of the scene is notable: The water streaming out of the jars of the gods is constituted in most cases by hieroglyphic signs in the shape of "life" ( $n h)$ and "dominion" (w3s). The positive effects that the purification should produce are made quite obvious thereby. The specific location of this scene is the area

\footnotetext{
59 thn is visible.

60 The reading htht is not secure.

61 Teissier, Egyptian Iconography, 48 no. 4 and 50; Eder, Ägyptische Motive, 74-78.

62 Kairo Catalogue Général 52004; see Graefe, "Sonnenaufgang", 63 no. 37.

63 Gardiner, "Baptism"; Assmann and Kucharek, "Wasserriten", 54-64.
} 
of entry into the temple, thus they are mostly engraved in the outer passageways of a temple.

The royal ritual has links to the ideal of the sun god, in which, according to the Egyptian conception, the morning purification precedes the sunrise. This can be seen very well in the section of the victory stelae of Piye in which he undertakes a kind of "pilgrimage" to Heliopolis. There, the text speaks of "Washing of his face with the river (water) of Nun with which Re washes his face". 64

The best evidence for the Egyptian king's palace as a location with access restricted according to purity is, paradoxically, a case that concerns not an original Egyptian king but a foreigner, namely the Nubian king Piye. On the large stela that he erected in memory of his victorious fights in Egypt is a report of how subject local Lower Egyptian potentates wanted to attend to the new ruler. Among them, only one is admitted, while the others have to wait outside. It is said:

Now these kings and leaders of Lower Egypt who came to see the perfection of his majesty, their position was like that of women, ${ }^{65}$ they could not enter the king's palace, because they were ' $m^{\prime}$ and had eaten fish. This is the taboo of the king's house. However, king Namelt entered the king's palace because he was pure and had not eaten fish. (Piye-Stela, l. 150-151) ) $^{66}$

The exact interpretation of this part is somewhat troublesome, as the lexical meaning of $\mathrm{m}^{\mathrm{c}}$ is problematic. For quite a long time it has been understood as "uncircumcised", but there is no substantial evidence for this. It should rather be understood as a kind of sexual activity. With the combination of sexual and food taboos, the rules correspond especially to the performance instructions in the Book of the Dead and to core issues of purity in later magical texts.

64 Grimal, Stèle triomphale, 130 and 136 note 402. For the larger context, see Kákosy, "Piye in Heliopolis".

65 So far this passage has always been translated as "their legs were (like) legs of women", which would be singular and hardly understandable in context. In reality, we have here the demotic $r t$ "position" (compare Copt. pHTє "way, kind"). The parallel sentence "they were not allowed to enter the palace" also pleads in favor of the new interpretation developed here. That women had generally less access authorization than men is clearly attested by the Book of the Temple.

66 Grimal, Stèle triomphale, $176-77$, and 178 note 529 . See the special study by GalpazFeller, "'Clean' and 'Unclean' ", who unfortunately takes the meaning "uncircumcised" for granted and therefore does not discuss its justification; see the short notes in Gozzoli, Writing of History, 56-57 with note 26 , who underlines the parallel of the king's palace and the temple of the god with regard to accessibility. 
There were likely specific ceremonies for the purification of the king around the turn of the year. A text transmitted in hieroglyphic inscriptions in the Ptolemaic temples in Philae, Assuan and Dendara might also belong to this context. ${ }^{67}$

The king of Upper and Lower Egypt, Lord of the two countries, Userkare beloved of Amun adores his mother; speaking words:

"Hail to you, Isis, great of magic,

Eldest in the womb of her mother Nut,

Effective in heaven with Re!

Praise to you in the day-barque,

Jubilation to you in the night-barque,

You who gave birth to all the gods!

The son of Re Ptolemaios has come to you, Lady of Life,

On this beautiful day in which you have appeared,

That he ties on for you your head,

That he fastens for you your neck.

Userkare beloved by Amun is your son Horus.

Your Ka is in peace, Lady of Life,

On this beautiful day in which you have appeared,

You whom the gods have pacified after the rage,

You of whom Re desires that you are within his barque

While repelling Apopis with the magic powers of your mouth.

Behold, Ptolemaios has come to you,

That he adores your perfection.

May you release him from all his damnations in the previous year,

His damnation of this year is removed-his back is towards it.

He has given offerings on account of them.

His countenance is towards you, mistress,

While you have come anew.

He has not done any malefaction of his town god,

He has not committed any $\sin ($ isf.t),

It shall not be counted against him in the council of the scribe of the two countries, ${ }^{68}$

Who assesses besmirchment in the course of the year,

Who transmits the offering cattle to the slaughtering block.

$\mathrm{He}$ is safe and sound from this year,

The retainers protect him.

In peace, in peace, good (new) year!

May he take hold of the offerings!

Your Ka shall be over him in life!"

67 Žabkar, Hymns to Isis, 66-67; pl. XVI right; in Philae Coppens, Wabet, 116-19. See Goyon, review of L. V. Žabkar, Hymns to Isis, 92-93.

68 That is, Thot. 
Here the text speaks of the relief from "damnations" (sç̣b.w); this word, whose usual translation is provisional, belongs to the category of things that need to be removed most frequently in purification rituals, besides "impurity" or "infection" ("b.w).

\section{Purification Rituals for Members of the Elite}

There are a number of rituals, which have received only scant attention in prior research, that primarily concern the protection and purification of Egyptians, presumably members of the elite. I have placed these rituals in the framework of antagonistic tensions at the Egyptian court, which are rarely spoken of explicitly. ${ }^{69}$ An interesting example in a papyrus of the Ramesside period is as follows:

A beautiful day! Your mouth is opened;

All your enemies among the dead and the living are quelled.

Horus pours water upon your fingers;

Geb (the god of the earth) hands over to you what is in him.

Your face is washed by your father Nun,

Your face is wiped dry by Hedjhotep(?).

Ptah turns towards you with the garment, like he did for Re.

Your mouth is opened with good utterances and choice expressions.

The good day is remembered for you

And forgotten for you is evil on the good day.

Heaven and earth are in festival, the gods in joy.

Jubilation is within the great caste, acclamation in the Benben-house.

May you receive food in the presence of the great ennead,

While everyone prays for health for you;

And your heart is full of rejoicing.

Nothing shabby which you have done will be reproached.

No evil shall attach to your limbs,

[...] shall be heard for you in presence of the lords of truth.

O NN whom NN has born,

Re purifies you at his coming forth, Thot at his shining forth,

When this utterance is told to you which Isis spoke to her son Horus:

"You are purified on the sixth day of the lunar month,

you are protected on the last day of the lunar month". (P. Chester Beatty IX

vs. B $12,10-13,9)$

(a long litany follows, then:)

"O you gods and goddesses whose names have been pronounced,

Who dwell in the sky but eat on earth,

69 See Quack, "Reinigen durch Anschwärzen"; Quack, "From Ritual to Magic". 
Whose uraei are on their heads, whose souls are in Busiris,

And their mummy forms in the necropolis, whose names are unknownBut you know their names, you know their occupations-

Come now and be gracious towards ... ${ }^{70}$

May you safeguard him, may you loosen him,

May you release him from all things bad and evil,

The water of every god and every goddess, every male and female demon,

Every male and female adversary,

Every male and female wandering spirit,

Every bitterness, every heat, ${ }^{71}$ every deafness, every blindness,

Every swelling (?), every thirst;

Every turmoil, every raging, every weakness,

Every enmity, every ...., every wrath,

Which exist hidden in every country in the course of each day!

You are protected, as the sun-god is protected day by day.

Your enemies are overthrown in the course of each day.

$\mathrm{NN}$ whom NN has born, he is the sun-god,

The sun-disc is on his head,

The gods protect him, the ennead safeguards him.

You are NN whom NN has born.

You belong to the gods whose names have been pronounced.

You have been born in front of the Kas of the living". (P. Chester Beatty vs.

$\mathrm{B} 17,4-18,7$ )

The instructions for the manual act contain the following:

This spell is recited over real lapis lazuli, turquoise, carnelian, amber (?), malachite (?), green feldspar, granite,..., iron and all precious stones, to be washed in milk, and the man shall be purified with it, as well as fumigating him with dust of barley. (P. Chester Beatty IX vs. B18, 7-10)

I would stress here that questions of purification are also touched upon, with the result that the effectuation of private purity, in which gods are utilized, goes hand in hand with overcoming opponents and rivals. The purification substances used in this case are notable, since milk, which is first used to wash gemstones, and grain dust have replaced the more normal substances, water and incense.

A similar combination is transmitted in a ritual spell for purification that forms a scene of the Ritual for Opening the Mouth on the one hand,

${ }^{70}$ Several doubtful words, perhaps corruptly transmitted.

71 Perhaps terms for skin diseases and inflammations; see for țr.t and šmm.t Quack, "Tabuisierte und ausgegrenzte Kranke", 69-70. With references, Fischer-Elfert, Abseits von Ma'at, 6o; 77-81. 
and on the other hand is already attested in an isolated instance in the early Middle Kingdom in a cosmetic scene, in a tomb. ${ }^{72}$

Hail to NN, may your purification be made in the room of homage of the king,

While you live, being renewed and rejuvenated as Re day by day!

Thot, the master of the gods' words, has praised, to justify your voice,

To throw down your enemies - they shall not exist!

One lexical point might be of importance in this connection. Within the Egyptian language, especially in earlier phases, the word $w^{c} b$ "to be pure" also has the special legal meaning "to be free of claims" ${ }^{73}$ The purification rituals studied here could thus also concern, at least partly, the situation of legal conflicts.

\section{PURITY FOR ORdinARY PEOPLE}

Before emphasizing that purity was eminently important for "the Ancient Egyptians", we should consider whether it holds true so simply and comprehensively. Purity in the domains we have explored hitherto is clearly a concern for the elites, not for the population at large. The purity rules in place for entering a temple were not continuously enforced in daily life and for obvious reasons could not have been. This is especially clear with regard to the sexual taboo, which would have led, with perpetual use, to the extinction of the Egyptian population within one or two generations. Likewise, in the case of food taboos it is clear that the fish, pigs and small livestock mentioned explicitly in the relevant texts were actually eaten in Ancient Egypt ${ }^{74}$ - only a few members of the elite could have covered their daily protein needs through cattle, geese and desert game. We can even prove positively that fish was a regularly delivered food item in the workman's village of Deir el-Medineh ${ }^{75}$ - and this for a group whose official occupation was to hew out and to decorate the royal tomb.

That purity by itself was not expected of the general population is shown by the regulations in Esna, which imposed special purity periods

72 See Quack, "Fragmente", 114-15.

${ }^{73}$ See Ritner, "Antecedents", 351 with note 56 .

74 See for pigs, e.g. El-Huseny, Inkonsequente Tabuisierung; for fish, Gamer-Wallert, Fische, 60-85; Elsbergen, Fischerei.

75 Compare for instance Valbelle, Ouvriers de la tombe, 272-74, who stresses that this seems to have been the most common aliment at this location besides bread. 
on the laypersons who either wanted to pray in the temple or had to work there as craftsmen.

However, the fact that the potential low purity of certain professionals was regarded not as neutral but, at least within the scribal elite, as negative is shown in a series of compositions in which the advantages of the scribal profession, as compared to all other professions, are listed. As a distinctive focus of the professions concerned, it is consistently stressed that those professions are dirty. ${ }^{76}$

A further important question concerns behavior towards foreigners. At least for the Late Period, there is evidence for a demarcation via purity conceptions. However, there are relatively few sources for this phenomenon in the Egyptian language. Although there are a few texts forbidding access to the temple for certain persons, ${ }^{77}$ it must be noted that these mostly concern not the whole temple complex but only certain areas, such as the crypts, to which only a few Egyptian priests had access. In addition, the original ethnic names ${ }^{\prime} m$ and $\check{s}_{3} s$ became, in the vernacular of the Late Period, professional names for herdsmen of cattle and sheep. In any case, there is concrete evidence that foreigners could become priests in an Egyptian temple. ${ }^{78}$

Furthermore, the biblical story of Joseph stresses that the Egyptians would not eat from the same table as the Hebrews (Gen 43:32). ${ }^{79}$ Other than this, the main external source is certainly Herodotus. He indicates that the Egyptians were very much concerned with purity, even cleaning the bronze beaker on a daily basis, wearing freshly washed linen garments, practicing circumcision for purity, and requiring that the priest shave his whole body daily and wear only a linen garment and sandals made of papyrus, in addition to washing twice a day and twice a night with cold water. They were not allowed to eat fish and beans (2.37). In addition, we also learn that they did not slaughter cows but only male cattle, and for this reason did not kiss any Greeks and would not use any Greek

\footnotetext{
76 See Jäger, Berufstypologien.

77 On this see e.g. Sauneron, Les fêtes religieuses d'Esna, 347-48 note o; Derchain, Papyrus Salt 825,168 note 83 .

78 Vittmann, "Beobachtungen".

79 See also Moers, "Speise der Asiaten", who tries to establish examples for the earlier existence of food taboos. However, they fail to convince: the stela of Piye is only concerned with purity rules for the royal palace as a place of specific purity, the letter of Mena concerns rather the act of establishing blood-brotherhood, and the prophecy of Neferti is not about food taboos but about suffering from requisitions by plundering Asiatics; in the annals of Amenemhet the modal interpretation by Moers (that the Egyptians had to eat Asiatic food) is not borne out by the Egyptian text.
} 
kitchenware (2.41). Another point in Herodotus indicative of differences in purity concepts between the two ethnicities is the treatment of the head of the sacrificial animal. At an Egyptian offering, many maledictions would be spoken over it and afterward, if there were any Greek traders nearby, it would be sold to them; otherwise it would be thrown into the river. All in all, the classification of Egyptians in contrast to other peoples where purity rules are concerned is not very explicit.

A peculiar trait, even if only marginally connected to the topic of purity, is inner-Egyptian differentiation. Many regionally defined taboos are valid only for inhabitants of a certain nome.$^{80}$ Regionally differentiated rules concerning which animals could or could not be eaten even had a real impact on delimitations and sometimes led to bloody inner-Egyptian conflicts. ${ }^{81}$ These differentiations within Egypt seem rather deeper-ranging than those against foreigners as such.

A special point concerns the question of purity rules for menstruating women ${ }^{82}$ and for women after birth. The Egyptian word for "menstruation", hsmn, is linked etymologically with the term for "purification". It is often assumed that women restricted themselves to certain rooms during menstruation. However, it is not easy to adduce clear evidence for this. The most pertinent cases seem to be certain demotic contracts in which the seller indicates to the buyer that his women could use a certain room during menstruation, or in cases with a woman as buyer, giving her this option directly. ${ }^{83}$ Similar cases also exist in some Greek documents. ${ }^{84}$ However, in actuality these texts stipulate only that the women could stay in those rooms during menstruation, not that they had to or that they were otherwise tainted with strong taboos. Moreover, the number of papyri in which such indications are mentioned is quite limited in comparison to the total number of demotic real estate documents preserved. The taboo of menstruating women, although it appears as a specific regional phenomenon in some nomes, is thus obviously not a comprehensive phenomenon. ${ }^{85}$

80 See e.g. Montet, "Fruit défendu"; Frandsen, "Menstrual 'Taboo' ", 87 note 21-23 with further references.

${ }^{81}$ See Quack, "Lokalressourcen", 27.

82 See in detail Wilfong, "Menstrual Synchrony"; Frandsen, "Menstrual 'Taboo'".

83 The most important sources are P. Louvre 2424; 2443; 2431, edited in Zauzich, Schreibertradition, 17-21; 21-26; 26-29; for the word for the room in question (but not explicitly the use during menstruation), see also P.BM 10446, Andrews, Catalogue, 66-67.

84 Colin, "Espace réservé".

85 Wilfong, "Menstrual Synchrony", 431. 
The chief witness regarding the question of purification after childbirth - or rather, the only substantial source - is P. Westcar. There, it is recounted that Ruddjedet, after she has borne three future kings, undergoes a purification period of 14 days (P. Westcar 11, 18-19) before she again takes up her house-keeping activities. ${ }^{86}$

Pointing to the phenomenon of the so called birth-houses in Egyptian temples, scholars have often thought that birth, and maybe even the whole pregnancy, happened in a special building outside the normal house. ${ }^{87}$ The theory of the so called "childbed arbor", which had been postulated as a specific place for the birth phase on the basis of picture ostraca of the New Kingdom, was attached to this. ${ }^{88}$ I regard this assumption with some skepticism. ${ }^{89}$ The P. Westcar itself relates that the gods, when they intend to help Ruddjedet give birth, come to the house of Ra-user, her husband (P. Westcar 10, 1-2). Nothing is written about a special building for the future mother. The pictures of the New Kingdom show, at most, some structure, but it cannot be demonstrated that it concerns a special childbed arbor outside the normal house, rather than simply an airy construction on the roof of the house that is preferred as a sleeping place during the summer heat. ${ }^{90}$

\section{PURity GUidelines FOR A TOMB}

Having eaten food by which a glorified being is disgusted and having had sexual intercourse with women before entering a tomb appear in an inscription of the Old Kingdom as reasons for a complaint being lodged in front of the gods' court. ${ }^{91}$ This case is formulated in uncommon detail.

${ }^{86}$ Brunner-Traut, "Wochenlaube", 23 , suggests a separation of the woman in childbed from the household because Ruddjedet inquires about the condition of the household. I would agree only so far as Ruddjedet did not look after anything in those 14 days and obviously had stayed in her room. There is no specific commentary on this in Lepper, Untersuchungen.

87 So firstly Chassinat, "Deux tableaux".

88 Brunner-Traut, "Wochenlaube"; see Vandier d'Abbadie, "Deux ostraca”, 21-29.

89 Also doubted by Daumas, Mammisis, 74-75 and 135 .

90 Brunner-Traut, "Wochenlaube", 20, admits that this arbor could have been on the roof or even have been the usual sleeping place. As crucial evidence for the spatial separation, she adduces modern ethnographic features (which are of doubtful value because they attest to the woman giving birth in the house of her parents, not the use of a separated arbor) as well as the birth-houses in the temples.

91 Silverman, "Threat-Formula", 10-11. The text itself in Kanawati and Abder-Raziq, Teti Cemetery, 38, pl. 59a, col. 1. 
Otherwise only a state of general purity and the avoidance of taboos are demanded, without a detailed indication of what exactly this entailed. ${ }^{92}$

\section{Purity for DeAd People ... or also for Living Ritualists}

The logical next step after the tomb is the purity of the corpse itself. There are several good indications that purification in the context of mummification was of some importance. Wall reliefs in tombs of the Old Kingdom already show the so-called purification tent. ${ }^{93}$ Purification scenes are also provided abundantly in connection with the funeral scenes, especially in front of the tomb. ${ }^{94}$

However, it must be noted that certain mourning customs do actually breach the rules of normal purity. The most glaring case concerns the hairstyle. Whereas under normal purity regulations a completely shaved head is desired, ${ }^{95}$ one lets one's hair grow long during the mourning period. ${ }^{96}$

Indeed, the end of that term is actually understood as a time of purification. This is most evident in the decree of Canopus (238 BCE). There (line 26 and 29 of the hieroglyphic text), Egyptian sw'b snm.t "to purify

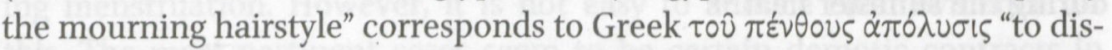
solve grief ". ${ }^{97}$ The final scene in the Book of the Death of Gatseschni from the 21st dynasty seems to me instructive in this regard. At the very end of the scroll is a purification scene, which is performed for the (female) owner. The usual colophon appears, but we also have the note, "The evil shall be to the earth as a mourning hairstyle". ${ }^{98}$ Thus we can see that the mourning period required abstention from the usual condition of purity as a sign of personal pain and sympathy, accepting impurity as a mortification. This in turn provides an opportunity to end the mourning period with a final purification and to reenter the usual state of purity.

92 See e.g. Edel, "Phraseologie", 4-8; Morschauser, Threat-Formulae.

93 See Grdseloff, Reinigungszelt; Vos, Apis Ritual, 157-58 with references.

94 Barthelmess, Übergang.

95 Perhaps also of the pubic area, as there are some depictions showing that. See Roth, Egyptian Phyles, 66-68; Grunert, "Nicht nur sauber".

96 Posener, Littérature et politique, 152.

97 Spiegelberg, Priesterdekrete; for a new study, see Pfeiffer, Dekret von Kanopus, 144-48 and 163-67; and an additional version in Tietze, Lange and Hallof, "Neues Exemplar".

98 For the translation, see Quack, "Kolophon"; see also Lucarelli, "Colophon", whose analysis, however, cannot be correct as the orthographies assumed by her for ' $r$, $m$ - $s z$ and $m w t$ are all excluded in a hieratic text of this time; her reasoning against my analysis that the word would be separated at the end of the line (p. 127) is flawed, as in hieratic texts of the 21st/22nd dynasty, breaking of words at the end of the line is quite normal. 
Shorter notes about mandatory purity can be found in abundance in the performance instructions in the postscripts of the Book of Death spells. Certain animal species, e.g. fish or small flock animals, are frequently proscribed, and abstinence from sexual intercourse is required..$^{99}$

However, this raises the question of how these texts are to be factually evaluated. Who should follow these purity rules and at what time? First of course we might think, in line with standard Egyptological reflexes, of the owner of the Book of the Death as a dead person. Soberly considered, however, such an approach is quite illogical. If this person were to conduct the ritual in the afterworld immediately after his death, he would have major problems with real purity, as he can hardly be expected to have observed "on spec" the many rules that are not permanently maintained, such as sexual abstinence. In contrast, if one thinks of a performance at the end of the embalming process, at the point of sepulture when the dead "arrives" in the afterworld, the specific postulation of purity rules would be absolutely unnecessary, as it can be assumed that the dead has neither eaten anything impure for 70 days nor had sexual intercourse; he would thus be long beyond all attested terms of purification.

Such rules are only reasonable for a real, living ritualist who performs the actions himself and thus can deliberately plan to fulfill the purity requirements. However, under these circumstances, further serious questions arise concerning the identity of the first-person speaker of the formulae. ${ }^{100}$ The Books of the Death usually introduce the first-person speaker with the phrase "speaking words by NN", where NN is the owner of the Book of Death, thus actually the deceased. How does this fit?

I see two options, which, however, both result in a performance by living people at least in the original state of using the text. ${ }^{101}$ The first option is a text that was not originally at home in the funerary sphere but rather had another usage, primarily in the temple cult. In this case the formulation in the first person is in accordance with acting instructions for the ritualist. The other solution is that the texts were actually used in a funeral context but that the speaker originally was not the dead but a still-living ritualist, who, for the benefit of the dead, performed a ritual. These texts

99 Stricker, Praehelleense Ascese; Eschweiler, Bildzauber, 258-61.

100 It is noteworthy that among the pyramid texts, all spells are cast in the third person (sometimes obviously changed) and manual instructions are almost totally lacking.

101 For the following, von Lieven, "Book of the Dead" is crucial; substantially important remarks also appear in Assmann, "Tod und Initiation". 
would then have come "in a package" into the literature provided for the dead.

Texts in the first person that do not feature the name of a specific individual as the beneficiary are especially important for the proper solution of this question. In particular, I think of cases like the papyri Gardiner 1-4, which both date very early (end of the Old Kingdom or First Intermediate Period) and use an anonymous first-person voice exclusively, thus indicating usage by a ritualist, but never mentioning a proper name.

Concerning purity instructions, I will illustrate these points with specific examples. As a first case I would point to BD 105.

Spell for satisfying the Ka, speaking words by NN:

"Hail to you, my Ka, my lifetime!

Behold, I have come to you,

Being effective, appearing, ensouled,

Being powerful, being healthy.

I have brought natron and incense to you,

That I purify you with it,

That I purify your sweat with it.

This bad utterance that I have said,

This evil impurity that I have committed,

It shall not be set against me(?),

Because mine is this green papyrus amulet,

Which is at the neck of Re,

Which was given to those $\mathrm{e}^{102}$ who are in the horizon.

If they prosper, I prosper!

My Ka prospers like them,

My Ka is fed like them.

The one who carries the scale, with noble truth ${ }^{103}$

At the nose of Re on that day!

You shall not carry me off(?), ${ }^{104}$

Because I have an eye which sees, an ear which hears!

I am no slaughtering cattle,

They shall not make me into offerings

For the chiefs - variant: chiefs and Nut!

May you let me pass you!

I am pure, justified is Osiris against his enemies!"

Hitherto, this text has been understood by Egyptologists as a relatively conventional speech of a dead person with the aim of rebirth. ${ }^{105}$ As a matter

102 Variant in Nebseni: "That those gave me who are in the horizon".

103 As $k$ i i is intransitive, I consider the translation "elevate Maat" impossible.

104 The exact sense of the expression tp-rmn is not clear.

105 Janák, "Journey to Resurrection". 
of fact, though, its focus is quite different. The aim is, on the one hand, to purify the Ka addressed as a recipient of the ritual; on the other hand, the individual emphasizes his own purity, or, more precisely, asks that his faults not be counted against him. With this, the possibility of being able to gain access to an area of limited access without being exposed to risks against body and life plays a major role. The only options that seem feasible to me are those of an officiant who arrives either to care for his dead forbear (namely, an ancestor) or to play the role of Horus for Osiris. ${ }^{106}$

My second example is a spell concerning passing the gates (BD 145). Only the first portal out of this long spell is cited as an example.

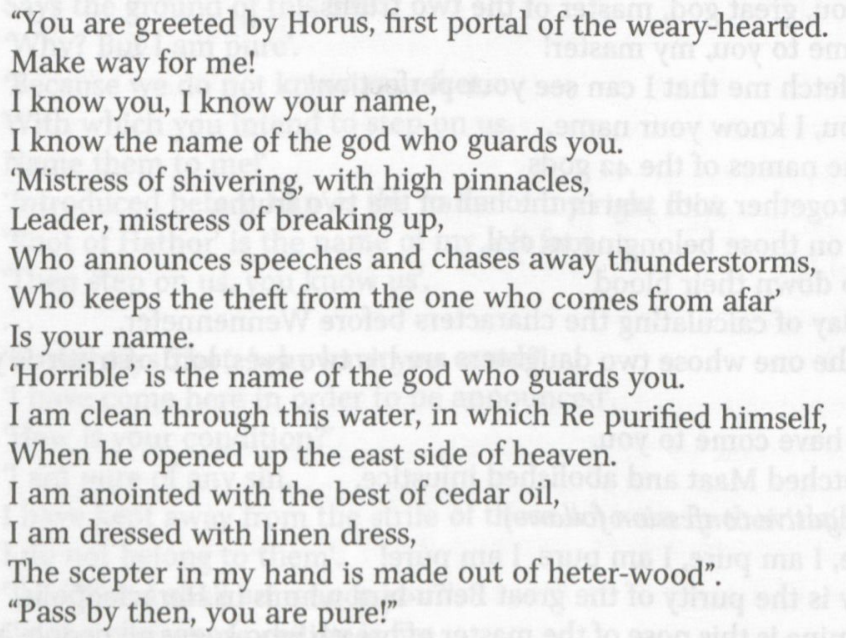

It must be noted that here purity connected with knowledge is essential, i.e., besides the correct purity and appropriate clothing, knowledge of the names of the door and the guardian is required. The assumption that this text is intended primarily for the ritualist is confirmed first by the introductory formula found in the most detailed version of the New Kingdom, in the tomb of Senenmut: "You are greeted by Horus"- thus the name is not changed to the name of the specific tomb owner. Second, we can see very clearly how this spell has been incorporated in the Late Period into an Osirian ritual in which the ritualist is definitely the living Horus,

106 As long as you do not accept that a still-living ritualist has to be differentiated from the dead, you quickly move into aporias in which the otherwise precise analysis by Willems, "Embalmer embalmed", ends. 
who acts for his father Osiris, ${ }^{107}$ and the destiny of the dead owner of the papyrus is linked to that of Osiris, not of Horus.

As a last example, I would like to cite a text that I might have been expected to treat under the aspect of purity conceptions in a moral sense, namely the well-known scene of the "judgment of the dead" in chapter 125 of the Book of the Dead. ${ }^{108}$ I will restrict myself to a few sections and will not treat the great confessions, which I regard as sufficiently wellknown.

What is said when reaching the hall of the two truths.

To separate NN from all misdeeds he has done, to see every god face-to-face: "Hail to you, great god, master of the two truths,

I have come to you, my master!

May you fetch me that I can see your perfection!

I know you, I know your name,

I know the names of the 42 gods

Who are together with you in the hall of the two truths,

Who live on those belonging to evil,

Who gulp down their blood

On that day of calculating the characters before Wennennefer.

Behold, 'the one whose two daughters are his two eyes, lord of truth' is your name!

Behold, I have come to you,

Having fetched Maat and abolished injustice,

(a long negative confession follows)

I am pure, I am pure, I am pure, I am pure!

My purity is the purity of the great Benu-bird who is in Heracleopolis,

Because mine is this nose of the master of breath who keeps all people alive,

On that day of filling the Udjat-eye in Heliopolis

In the second month of the time of sowing at the last day.

In front of the master of this land.

It is me who sees the filling of the Udjat-eye in Heliopolis.

Nothing evil shall happen against me in this country,

In this hall of the two truths,

Because I know the name of these gods who are in her following the great god.

(the negative confession addressed to the 42 gods follows)

Hail to you, you gods!

I know you, I know your names!

I shall not fall to your massacre,

You shall not let my evil ascend to this god whom you are following,

My (mis)deed shall not occur with you,

107 Goyon, Imouthès, 17-47; Smith, Traversing Eternity, 67-95.

108 New synoptic text edition in Lapp, Spruch 125. 
You shall speak the truth concerning me in front of the Almighty!

Because I have committed the Maat in Egypt,

I have not blasphemed any god,

My (mis)deed has not occurred with the incumbent king.

I am pure, my forepart is in purity,

My back part is in cleanliness,

My middle is a pond of Maat,

No limb of myself is free of Maat.

I have purified myself in the southern pond,

‥

'I will not let you step on me'

Says the ground of this hall.

'Why? But I am pure'.

'Because we do not know your feet,

With which you intend to step on us.

Name them to me!'

'Introduced before Min' is the name of my right foot,

'Root of Hathor' is the name of my left foot.

'Then step on us, you know us'.

...

'Come' says Thot, 'why have you come?'

'I have come here in order to be announced'.

'How is your condition?'

'I am pure of any sin,

I have kept away from the strife of those who are in their daily service,

I do not belong to them'.

'To whom I shall announce you?'

"To the one whose ceiling is fire,

Whose walls are reared Uraei,

Whose ground is the flood'.

'Who is that?'

'That is Osiris'.

'Thus pass by, you are announced!

Your bread is the Udjat-eye,

Your beer is the Udjat-eye,

You will be brought offerings on earth consisting of the Udjat-eye'

- thus he says about me.

\section{Postscript}

To be performed as it happens in the halls of the two truths. A man shall say this spell being pure and clean, after he has dressed in garments of the channel shore(?), the sandals as white sandals, made-up with malachite, anointed with myrrh of best quality, having sacrificed a fresh cow, poultry, incense, bread, beer and vegetables. Now you do this pattern as a drawing with ochre on the pure ground coated with soil on which no pig or goat has stepped. As for the one on whom this book is performed, he will be 
prosperous, his children will be prosperous, he will be a confidant of the king and his royal court, he will be given a shenes-bread, a jar with beer, per-sen-bread, a big piece of meat from the altar of the great god, he will not be repelled at all doors in the west. He will be transported together with the kings of Upper and Lower Egypt, he will be in the cortege of Osiris. A true remedy, proven a million times.

The text is of relevance as it is focused on purity. It is explicitly called a ritual for the separation of misdeeds in the title, i.e., the aim is a statement of purity that also eliminates any possible mistakes. Besides purity, knowledge that legitimizes access is also necessary in this case; after finishing the confessions, the candidate has to prove his knowledge of different religious customs and names, of which only one case is included in the translation above. If we detach ourselves from the traditional Egyptological approach, we can see quite well that the actual aim of the spell is to receive a secure supply, on the one hand, and to gain access, on the other hand. The note in the postscript that the ritualist would be a confidant of the king and of his royal court raises the suspicion that we have an original court ritual concerning direct contact, on par with the highest elite, here.

An older source for purity regulations of similar difficulty is to be found in the so-called Book of the Two Ways, which is transmitted on coffins from the early Middle Kingdom but which goes back to original priestly rituals in the Osirian and solar domains, in my opinion. At the corresponding position (CT VII $449, \mathrm{~d}-\mathrm{e}$ ), it is said:

If a man sets out to go to the west, then the man shall recite in a purity period of four days and on his fourth day he shall go forth.

If I understand this text correctly (my analysis diverges seriously from most former editors), ${ }^{109}$ then a purity term of four days of preparation for the ritual is demanded.

In addition, a totally different form of justifying access, this time clearly in a non-funeral field, is to be found in a text that in its first modern edition has been given the rather unfortunate title "Book of Thot"; it is actually a ritual for access to the chamber of darkness. ${ }^{110}$ The text's main goal is the initiation of a scribe into the arcane secrets. The important section is as follows:

109 See, in a slightly different sense, Backes, Zweiwegebuch, 11 .

110 Jasnow and Zauzich, Book of Thoth; Quack, "Initiation"; Quack, "Dialog". 
[He-spoke-in-Hesrekh] said: 'If you smell of myrrh, then do not enter the House of Life! They are horny bulls which are in [it].

Is there a woman for you? Do you have any daughters? Then take care!

[...] you; or is it a father, who sent you out? It is the teaching of the boy (?) who is worthy to examine you'.

The one loving wisdom says: 'I know the taboos which are in the chamber of darkness, I have come free of them.

I have turned wine into an abomination for me, I have forgotten the smell of the myrrh. Behold, my dresses are tattered, I am desirous!'

He-spoke-in-Hesrekh said: 'The Ibises which are her, their food is tiresome, their life is problematic.

They do not satiate themselves with bread, they do not get drunk by wine, they do not anoint themselves with ointment. Their taboo is to mention the name of the sexual intercourse.

Arrow demons (?) are what stand at their mouth, and snakes on their lips.

Their offerings are dogs, their food is donkeys, their fruits are reptiles.

Will you be able to live with those who are in earth holes? What is their way to serve them?'

The one loving wisdom said: 'I will wash their writing bowls, I will rinse their writing boards (?), I will wipe off the dust of their boxes.

I will fill up the rest, I will light the torch, I will prepare charcoal for the temple houses.

I will break the stones (?), I will hug the boxes, I will produce [...].

I will receive the boxes (?), I will rush on the voice, I will open [the doors(?)].

I will carry the writing rolls on the way behind them, I will [...]'

Some of these taboos are similar to the purity instructions in rituals, especially the avoidance of contact with women. In general, however, they quite definitely concern mortifications, demonstrating a conscious abstention from the conveniences of life. In some points, especially with regard to tattered clothes and abstention from ointment and scents, they create a state diametrically opposed to the normal concept of purity.

Advice concerning the necessity of purity is quite common in GrecoEgyptian magical papyri, which are partly demotic but mostly transmitted in Greek. These certainly concern a living ritualist, and in view of the aims of the rituals, they were used outside the normal temple cult establishment. They very often emphasize that the question of purity is crucial for the efficacy of the ritual. ${ }^{111}$ Where they become explicit, the concrete points are similar to the older Egyptian texts, as well as to the Book of the Dead postscripts and the access texts of the Greco-Roman temple: sexual taboo, no food from pig and fish, pure garments and ritual implements.

11 Compare Quack, "Postulated and Real Efficacy". 
The most common time span for purity terms is three days, sometimes seven. Much more complex is the ritual in the eighth Book of Moses, which requires a preparation period of 41 days. It should be noted that these instructions appear with rituals concerning not an urgent crisis but predictable situations, especially divination rituals.

\section{Final Remarks}

Purity in Egypt has a delimiting function-certain rooms and persons are only accessible if their requirements have been fulfilled; certain social groups, especially priests, assert themselves through them. At the same time, however, it is also a limited matter. Most purity instructions are only valid for a certain period and in a certain situation and do not have to be kept permanently.

A possible differentiation of purity in the physical and the moral sense hardly seems possible. ${ }^{112}$ Normally, in the text of a ritual, the physical aspect is more strongly emphasized, but the material presented here demonstrates well that the moral aspect is attached seamlessly.

\section{BIBLIOGRAPHY}

Alliot, Maurice. Le culte d'Horus à Edfou au temps des Ptolémées. Bibliothèque d'Étude 20. Cairo: Institut français d'archéologie orientale, 1949-54.

Altenmüller-Kesting, Brigitte. "Reinigungsriten im Ägyptischen Kult". Ph.D. diss. Hamburg 1968.

Andrews, Carol. Catalogue of Demotic Papyri in the British Museum, Volume IV: Ptolemaic Legal Texts from the Theban Area. London: British Museum, 1990.

Assmann, Jan. Altägyptische Totenliturgien: Band 3: Osirisliturgien der Spätzeit. Heidelberg: Winter, 2008.

—. "Tod und Initiation im altägyptischen Totenglauben". Pages 336-59 in Sehnsucht nach dem Ursprung. Zu Mircea Eliade. Edited by H. P. Duerr. Frankfurt on the Main: Syndikat, 1983 .

Assmann, Jan, and Kucharek, Andrea. "Wasserriten im Alten Ägypten”. Pages 43-68 in Ablution, Initiation, and Baptism. Late Antiquity, Early Judaism, and Early Christianity. Edited by D. Hellholm, T. Vegge, CE. Norderval, and Chr. Hellholm. Berlin/Boston: de Gruyter, 2011.

Aufrère, Sydney. L'univers minéral dans la pensée égyptienne. Bibliothèque d'Étude 105. Cairo: Institut français d'archéologie orientale, 1991.

__. "Etudes de lexicologie et d'histoire naturelle VIII-XVII: Remarques au sujet des végétaux interdits dans le temple d'Isis à Philae". Bulletin de l'Institut Français d'Archéologie Orientale 86 (1986): 1-32. 
Backes, Burkhard. Das Altägyptische 'Zweiwegebuch': Studien zu den Sargtext-Sprüchen 1029-1130. Ägyptologische Abhandlungen 69. Wiesbaden: Harrassowitz, 2005.

Barthelmess, Petra. Der Übergang ins Jenseits in den thebanischen Beamtengräbern der Ramessidenzeit. Studien zur Archäologie und Geschichte Altägyptens 2. Heidelberg: Heidelberger Orientverlag, 1992.

Blackman, Aylward M. "Sacramental Ideas and Usages in Ancient Egypt". Proceedings of the Society for Biblical Archaeology 11 (1918): 57-66 and 86-91.

- "Some Notes on the Ancient Egyptian Practice of Washing the Dead". Journal of Egyptian Archaeology 5 (1918): 117-24.

- "The House of the Morning" Journal of Egyptian Archaeology 5 (1918): 148-65.

- "Purification (Egyptian)". Pages $476-82$ in vol. 10 of Encyclopedia of Religion and Ethics. Edited by J. Hastings. 12 vols. New York: Scribner's, 1918.

Bricault, Laurent. Recueil des inscriptions concernant les cultes isiaques: (RICIS): Vol. 1Corpus. Mémoires de l'Académie des Inscriptions et Belles-Lettres 31. Paris: de Boccard, 2005.

Brunner-Traut, Emma. "Die Wochenlaube". Mitteilungen des Instituts für Orientforschung 3 (1955): 11-30.

Burgos, Franck, and François Larché. La Chapelle Rouge: Le sanctuaire de barque d'Hatshepsout: Volume 1: Fac-similés et photographies des scènes. Paris: Culturesfrance, 2006.

Chassinat, Émile. “À propos de deux tableaux du mammisi d'Edfou”. Bulletin de l'Institut Française d'Archéologie Orientale 10 (1912): 183-93.

Colin, F. “Un espace réservé aux femmes dans l'habitat hellénistique d'après des papyrus grecs et démotiques". Pages 259-68 in Atti del XXII Congresso Internazionale di papirologia: Firenze 23-29 agosto 1998. Edited by I. Andorlini. Florence: Istituto papirologico G. Vitelli, 2001.

Coppens, Filip. The Wabet: Tradition and Innovation in Temples of the Ptolemaic and Roman Period. Prague: Czech Institute of Egyptology, 2007.

Crevatin, Franco. Il libro dei morti di Ptahmose (Papiro Busca, Milano) ed altri documenti egiziani antichi. Biblioteca degli Studi di egittologia e di papirologia 6. Pisa: Fabrizio Serra, 2008.

Daumas, François. Les Mammisis des temples égyptiens. Paris: Les Belles Lettres, 1958.

Derchain, Philippe. Le papyrus Salt 825 (B.M. 10051), rituel pour la conservation de la vue en Égypte. Brussels: Académie royale de Belgique, 1965.

Douglas, Mary. Purity and Danger: An Analysis of Concept of Pollution and Taboo. London: Routledge \& Kegan Paul, 1966. Repr., London: Routledge \& Kegan Paul, 2006.

. Leviticus as Literature. Oxford: Oxford University Press, 1999.

Edel, Elmar. "Untersuchungen zur Phraseologie der ägyptischen Inschriften des Alten Reiches". Mitteilungen des Deutschen Archäologischen Instituts Kairo 13 (1944): 1-90.

Eder, Christian. Die ägyptischen Motive in der Glyptik des östlichen Mittelmeerraumes zu Anfang des 2. Jts. v. Chr. Orientalia Lovaniensia Analecta 71. Leuven: Peeters, 1995.

Elsbergen, Michael Johannes van. Fischerei im Alten Ägypten: Untersuchungen zu den Fischfangdarstellungen in den Gräbern der 4. bis 6. Dynastie. Abhandlungen des Deutschen Archäologischen Instituts Kairo: Ägyptologische Reihe 14. Berlin: Achet Verlag, 1997.

Eschweiler, Peter. Bildzauber im Alten Agypten: Die Verwendung von Bildern und Gegenständen in Magischen Handlungen nach den Texten des Mittleren und Neuen Reiches. Orbis Biblicus et Orientalis 137. Fribourg: Universitätsverlag, 1994.

Fairman, Herbert W. "Worship and Festivals in an Egyptian Temple". Bulletin of the John Rylands Library 37 (1954): 165-203.

Fischer-Elfert, Hans-Werner. Abseits von Ma'at: Fallstudien zu Außenseitern im Alten Ägypten. Wahrnehmungen und Spuren Altägyptens 1. Würzburg: Ergon, 2005.

Frandsen, Paul J. “The Menstrual 'Taboo' in Ancient Egypt”. Journal of Near Eastern Studies 66 (2007): 81-105. 
Galpaz-Feller, Pnina. “The Stela of King Piye: A Brief Consideration of 'Clean' and 'Unclean' in Ancient Egypt and the Bible". Revue Biblique 102 (1995): 506-21.

Gamer-Wallert, Ingrid. Fische und Fischkulte im Alten Ägypten. Ägyptologische Abhandlungen 21. Wiesbaden: Harrassowitz, 1970.

Gardiner, Allen Henderson. "The Baptism of Pharaoh". Journal of Egyptian Archaeology 36 (1950): 3-12.

Gee, John. "The Requirements of Ritual Purity in Ancient Egypt". Ph.D. diss. Yale University 1998.

Goyon, Jean-Claude. Le papyrus d'Imouthès, fils de Psinthaês au Metropolitan Museum of Art de New-York: (Papyrus MMA 35.9.21). New York: Metropolitan Museum of Art, 1999.

- Review of L. V. Žabkar, Hymns to Isis in Her Temple at Philae. Chronique d'Égypte 68 (1993): 87-93.

- Confirmation du pouvoir royal au nouvel an: Brooklyn Museum Papyrus 47.218.50. Bibliothèque d'Étude 52. Cairo: Institut français d'archéologie orientale, 1972.

- "Une formule solennelle de purification des offrandes dans les temples ptolémaïques". Chronique d'Égypte 45 (1970): 267-81.

Gozzoli, Roberto B. The Writing of History in Ancient Egypt during the First Millennium $B C$ (ca. 1070-180 BC): Trends and Perspectives. Golden House Publications Egyptology 5. London: Golden House Publications, 2006.

Graefe, Erhard. "Der Sonnenaufgang zwischen den Pylontürmen"-Erstes Bad, Krönung und Epiphanie des Sonnengottes à propos Carter, Tut-anch-Amen, Handlist no 181 ". Orientalia Lovaniensia Periodica 14 (1983): 55-79.

Grdseloff, Bernhard. Das Ägyptische Reinigungszelt. Études égyptiennes 1. Cairo: Institut français d'archéologie orientale, 1941.

Grieshammer, Reinhard. "Zum Fortleben ägyptischer und israelitisch-jüdischer Unschuldserklärungen in frühchristlichen Texten Ägyptens". Pages 247-64 in Jerusalem Studies in Egyptology. Ägypten und Altes Testament 40. Edited by I. Shirun-Grumach. Wiesbaden: Harrassowitz, 1998.

—. "Reinheit, Kultische". Pages 212-13 in vol. 1 of Lexikon der Ägyptologie. Edited by W. Helck and O. Eberhard. 7 vols. Wiesbaden: Harrassowitz, 1984.

Grimal, Nicolas. La stèle triomphale de Pi('ankh)y au Musée du Caire: JE 48862 et 4708647089. Mémoires publiés par l'Institut Française d'Archéologie Orientale 105. Cairo: Institut français d'archéologie orientale, 1981.

Grunert, Stefan. "Nicht nur sauber, sondern rein: Rituelle Reinigungsanweisungen aus dem Grab des Anchmahor in Saqqara". Studien zur Altägyptischen Kultur 30 (2002): 137-51.

Guermeur, Ivan. “À propos d'un nouvel exemplaire du rituel journalier pour Soknebtynis (phiéraTeb SCA 2979 et autres variantes)". In Ägyptische Rituale der Griechisch-Römischen Zeit. Edited by J. F. Quack. Tübingen: Mohr Siebeck, forthcoming.

Guglielmi, Waltraud, and Knuth Buroh. "Die Eingangssprüche des täglichen Tempelrituals nach Papyrus Berlin 3055 (I, 1-VI, 3)". Pages 101-66 in Essays on Ancient Egypt in Honour of Herman te Velde. Egyptological Memoirs 1. Edited by J. van Dijk. Groningen: Styx Publications, 1997.

Gutbub, Adolphe. Textes fondamentaux de la théologie de Kom Ombo. Bibliothèque d'Étude 47. Cairo: Institut français d'archéologie orientale, 1973.

Habachi, Labib. The Sanctuary of Heqaib: Elephantine 4. Archäologische Veröffentlichungen 33. Mainz on the Rhine: Philipp von Zabern, 1985.

Hieratische Papyri aus den Königlichen Museen zu Berlin, Erster Band: Rituale für den Kultus des Amon und für den Kultus der Mut. Leipzig: J. C. Hinrichs, 1901.

Hornung, Erik. Der Eine und die Vielen: Ägyptische Gottesvorstellungen. Darmstadt: Wissenschaftliche Buchgesellschaft, 1971.

Horst, Pieter Willem van der. Chaeremon: Egyptian Priest and Stoic Philosopher: The Fragments Collected and Translated with Explanatory Notes. Études préliminaires aux religions orientales dans l'Empire romain 101. 2d ed. Leiden: Brill, 1987. 
El-Huseny, Abd El-Hamid M. Die Inkonsequente Tabuisierung von Sus Scrofa Linnaeus, 1758 im Alten Ägypten: Seine Ökonomische und Religiöse Bedeutung. Berlin: Wissenschaftlicher Verlag, 2006.

Jäger, Stephan. Altägyptische Berufstypologien. Lingua Aegyptia: Studia monographica 4. Göttingen: Seminar für Ägyptologie und Koptologie, 2004.

Janák, Jiři. "Journey to Resurrection: Chapter 105 of the Book of the Dead in the New Kingdom". Studien zur Altägyptischen Kultur 31 (2003): 193-210.

Jasnow, Richard, and Karl-Theodor Zauzich. The Ancient Egyptian Book of Thoth: A Demotic Discourse on Knowledge and Pendant to the Classical Hermetica. Wiesbaden. Harrassowitz, 2005.

Junker, Hermann. "Vorschriften für den Tempelkult in Philä". Pages 151-6o in Studia Biblica et Orientalia: Vol. 3. Oriens Antiquus: Analecta Biblica 12. Rome: Pontificio Istituto Biblico, 1959.

Kákosy, László. "King Piye in Heliopolis". Pages 321-29 in A Tribute to Excellence: Studies Offered in Honor of Ernó Gaál, Ulrich Luft, László Török. Studia Aegyptiaca 17. Edited by T. A. Bács. Budapest: La chaire d'égyptologie, 2002.

Kanawati, Naguib, and Mahmoud Abder-Raziq. The Teti Cemetery at Saqqara: Vol. 5. The Tomb of Hesi. Warminster: Aris and Philipps, 1999.

Kurth, Dieter. Treffpunkt der Götter: Inschriften aus dem Tempel des Horus von Edfu. Rev. and enl. ed. Zurich: Artemis \& Winkler, 1998.

Lapp, Günther. Totenbuch Spruch 125. Totenbuchtexte 3. Basel: Orientverlag, 2008.

Leitz, Christian. Die Tempelinschriften der Griechisch-Römischen Zeit. Quellentexte zur Ägyptischen Religion 1. Einführungen und Quellentexte zur Ägyptologie 2. 2d ed. Münster: LIT-Verlag, 2006.

Lepper, Verena. Untersuchungen zu pWestcar: Eine Philologische und Literaturwissenschaftliche (Neu-)Analyse. Ägyptologische Abhandlungen 70. Wiesbaden: Harrasowitz, 2008.

Lieven, Alexandra von. "Book of the Dead, Book of the Living: BD Spells as Temple Texts". Journal of Egyptian Archaeology, forthcoming.

Lorton, David. "The Theology of Cult Statues in Ancient Egypt". Pages 123-210 in Born in Heaven, Made on Earth: The Making of the Cult Image in the Ancient Near East. Edited by M. B. Dick. Winona Lake, Ind.: Eisenbrauns, 1999.

Lucarelli, Rita. "The Colophon of the Book of the Dead of Gatseschen: A Working Issue". Göttinger Miszellen 220 (2009): 125-27.

Meeks, Dimitri. Mythes et légendes du Delta:D'après le papyrus Brooklyn 47.218.84. Mémoires publiés par les Membres de l'Institut Français d'Archéologie Orientale 125. Cairo: Institut français d'archéologie orientale, 2006.

- "Pureté et purification en Égypte". Col. $430-52$ in Dictionnaire de la Bible: Supplément 9. Edited by L. Pirot. Paris: Letouzey et Ané, 1979.

Menchetti, Angiolo. Ostraka demotici e bilingui da Narmuthis (ODN 100-188). Biblioteca di studi egittologici 5. Pisa: Edizioni ETS, 2005.

Meyer, Robert. "Magical Ascesis and Moral Purity in Ancient Egypt". Pages 45-64 in Transformations of the Inner Self in Ancient Religions. Studies in the History of Religions 83. Edited by J. Assmann and G. G. Stroumsa. Leiden: Brill, 1999.

Moers, Gerald. “'Jene Speise der Asiaten': Zur bisher unbekannten Vorgeschichte Spätzeitlicher Speisetabus". Pages 507-16 in Altertum und Mittelmeerraum: Die Antike Welt diesseits und jenseits der Levante: Festschrift für Peter W. Haider zum 6o. Geburtstag. Oriens et Occidens 12. Edited R. Rollinger and B. Truschnegg. Stuttgart: Franz Steiner Verlag, 2006.

Montet, Pierre. "Le fruit défendu". Kêmi n (1950): 85-116.

Moret, Alexandre. Le rituel du culte divin journalier en Égypte: D'après les papyrus de Berlin et les textes du temple de Séti Ier, à Abydos. Musée Guimet: Annales du Musée Guimet: Bibliothèque d'études 14. Paris: Leroux, 1902. 
Morschauser, Scott N. Threat-Formulae in Ancient Egypt: A Study of the History, Structure and Use of Threats and Curses in Ancient Egypt. Baltimore, Md.: Halgo, 1991.

Musso, Simone, and Simone Pettacchi. "Sexual Taboos and Priestly Functions in Ancient Egypt". Pages 545-66 in Second International Congress for Young Egyptologists. Edited by P. Veiga. Lisbon: Centro de História, 2010.

Osing, Jürgen, and Gloria Rosati. Papiri geroglifici e ieratici da Tebtunis. Florence: Istituto paprirologico G. Vitelli, 1998.

Otto, Eberhard. Das Ägyptische Mundöffnungsritual. Ägyptologische Abhandlungen 3. Wiesbaden: Harrassowitz, 1960.

Parker, Robert. Miasma:Pollution and Purification in Early Greek Religion. Oxford: Clarendon Press, 1983. 3d ed. Repr., Oxford: Clarendon Press, 2003.

Patillon, Michel, Alain Ph. Segonds, and Luc Brisson. Porphyre, De l'abstinence, tome 3. Livre 4. Collection des universités de France 368 Série grecque. Paris: Les Belles Lettres, 1995.

Pfeiffer, Stefan. Das Dekret von Kanopus (238v. Chr.): Kommentar und historische Auswertung eines dreisprachigen Synodaldekretes der Ägyptischen Priester zu Ehren Ptolemaios' III. und seiner Familie. Archiv für Papyrusforschung Beiheft 18. Munich: K. G. Saur, 2004.

Posener, Georges. Littérature et politique dans l'Égypte de la XII' dynastie. Bibliothèque de l'École des Hautes Etudes 307. Paris: Librairie Honoré Champion, 1956.

Quack, Joachim Friedrich. "From Ritual to Magic: Ancient Egyptian Forerunners of the Charitesion and their Social Setting". In Continuity and Innovation in the Magical Tradition. Edited by G. Bohak, Y. Harari and S. Shaked. Leiden: Brill, forthcoming.

_ _ . "Les normes pour Osiris et son culte: Les indications du Manuel du Temple sur les lieux et les prêtres". In Les cultes d'Osiris au r $^{\text {er }}$ millénaire. Edited by L. Coulon. Cairo: Institut français d'archéologie orientale, forthcoming.

—. "Reinigen durch Anschwärzen?" In How Purity is made. Edited by P. Rösch and

U. Simon. Wiesbaden: Harrassowitz, forthcoming.

- "Translating the Realities of Cult: The Case of the Book of the Temple". In Aegypto-

Graeca: Literary Interactions between Greece and Egypt, $700 \mathrm{BC}-300 \mathrm{AD}$. Edited by

I. Rutherford. forthcoming.

- "Postulated and Real Efficacy in Late Egyptian Antique Rituals". Journal of Ritual Studies 24 (2010): 45-60.

—_. "Lokalressourcen oder Zentraltheologie? Zur Relevanz und Situierung geographisch strukturierter Mythologie im Alten Ägypten”. Archiv für Religionsgeschichte 10 (2008): $5^{-29 .}$

- "Zum Kolophon des Totenbuchs der Gatseschen". Göttinger Miszellen 218 (2008): 7-8.

- "Die Initiation zum Schreiberberuf im Alten Ägypten". Studien zur Altägyptischen Kultur 36 (2007): 249-95.

_. "Ein Ägyptischer Dialog über die Schreibkunst und das arkane Wissen". Archiv für Religionsgeschichte 9 (2007): 259-94.

_. "Fragmente des Mundöffnungsrituals aus Tebtynis". Pages 69-150 in The Carlsberg Papyri 7: Hieratic Texts from the Collection. CNI Publications 30. Edited by K. Ryholt. Copenhagen: Museum Tusculanum Press, 2006.

- "Ein Prätext und seine Realisierungen: Aspekte des Ägyptischen Mundöffnungsrituals". Pages $165-85$ in Text und Ritual: Essays und Kulturwissenschaftliche Studien von Sesostris bis Dada. Hermeia 8. Edited by B. Dücker and H. Roeder. Heidelberg: Synchron, 2005 .

- Review of S. Lippert, Ein Demotisches Juristisches Lehrbuch. Archiv für Papyrusforschung 51 (2005): 171-74.

-. "Tabuisierte und ausgegrenzte Kranke nach dem 'Buch vom Tempel' ". Pages 63-80

in Papyrus Ebers und die Antike Heilkunde: Akten der Tagung vom 15.-16. 3. 2002 in der Albertina/UB der Universität Leipzig. Philippika 7. Edited by H.-W. Fischer-Elfert. Wiesbaden: Harrassowitz, 2005. 
—_. "Organiser le culte ideal: Le Manuel du temple égyptien". Bulletin de la Société Française d'Égyptologie 16o (2004): 9-25.

_. "Le manuel du temple: Une nouvelle source sur la vie des prêtres égyptiens". Égypte Afrique \& Orient 29 (2003): 11-18.

—. "Königsweihe, Priesterweihe, Isisweihe". Pages 95-108 in Ägyptische Mysterien?. Edited by J. Assmann and M. Bommas. Munich: Wilhelm Fink, 2002.

- "Das Buch vom Tempel und Verwandte Texte: Ein Vorbericht". Archiv für Religionsgeschichte 2 (2000): 1-20.

- Studien zur Lehre für Merikare. Göttinger Orientforschungen 4,23. Wiesbaden: Harrassowitz, 1992.

Quirke, Stephen. "Two Thirteenth Dynasty Heart Scarabs". Jaarbericht van het vooraziatisch-egyptisch genootschap Ex Oriente Lux 37 (2003): 31-40.

Ritner, Robert K. "Third Intermediate Period Antecedents of Demotic Legal Terminology". Pages 343-59 in Acts of the Seventh International Conference of Demotic Studies, Copenhagen, 23-27 August 1999. CNI Publications 27. Edited by K. Ryholt. Copenhagen: Museum Tusculanum, 2002.

Roth, Ann Macey. Egyptian Phyles in the Old Kingdom: The Evolution of a System of Social Organization. Studies in Ancient Oriental Civilizations 48. Chicago: University of Chicago 1991.

Sauneron, Serge. Les fêtes religieuses d'Esna aux derniers siècles du paganisme. Esna 5 . Cairo: Institut français d'archéologie orientale, 1962.

Schott, Siegfried. Kanais. Der Tempel Sethos I. im Wadi Mia. Nachrichten der Akademie der Wissenschaften Göttingen, phil.-hist. Klasse 1961,6. Göttingen: Vandenhoeck \& Ruprecht, 1961.

-Die Reinigung Pharaos in einem Memphitischen Tempel: (Berlin P. 13242). Nachrichten der Akademie der Wissenschaften Göttingen, phil.-hist. Klasse 1957,3. Göttingen: Vandenhoeck \& Ruprecht, 1957.

Silverman, David P. "The Threat-Formula and Biographical Text in the Tomb of Hezi at Saqqara". Journal of the American Research Center in Egypt 37 (2000): 1-13.

Smith, Aaron. "Kingship, Water and Ritual: The Ablution Rite in the Coronation Ritual of the Pharaoh". Pages 329-36 in L'acqua nell'antico Egitto: Vita, rigenerazione, incantesimo, medicamento: Proceedings of the First International Conference for Young Egyptologists, Italy, Chianciano Terme October 15-18, 2003. Egitto antico 3: Atti 1. Edited by A. Amenta, M. M. Luiselli and M. N. Sordi. Rome: L'Erma di Bretschneider, 2005.

Smith, Mark. Traversing Eternity: Texts for the Afterlife from Ptolemaic and Roman Egypt. Oxford: Oxford University Press, 2009.

Spiegelberg, Wilhelm. Der Demotische Text der Priesterdekrete von Kanopus und Memphis (Rosettana). Heidelberg: Privately printed, 1922.

Stricker, Bruno Hugo. De praehelleense Ascese. Leuven: Peeters, 1994.

Tacke, Nikolaus. "Das Opferritual des Ägyptischen Neuen Reiches". Pages 27-36 in Rituale in der Vorgeschichte, Antike und Gegenwart: Studien zur Vorderasiatischen, Prähistorischen und Klassischen Archäologie, Ägyptologie, Alten Geschichte, Theologie und Religionswissenschaft: Interdisziplinäre Tagung vom 1.-2. Februar 2002 an der Freien Universität Berlin. Edited by C. Metzner-Nebelsick, O. Dally, A. Hausleiter, E. Kaiser, H. Peter-Röcher, I. Prohl, J. F. Quack and F. Rumscheid. Rhaden, Germany: Marie Leidorf, 2003.

Teissier, Beatrice. Egyptian Iconography on Syro-Palestinian Cylinder Seals of the Middle Bronze Age. Orbis Biblicus et Orientalis: Series Archaeologica 11. Fribourg: Universitätsverlag Fribourg, 1996.

Tietze, Christian, Eva R. Lange, and Klaus Hallof. "Ein neues Exemplar des KanopusDekrets aus Bubastis". Archiv für Papyrusforschung $5_{1}(2005)$ : 1-29, pl. I-III and X-XI.

Valbelle, Dominique. Les ouvriers de la tombe: Deir el-Médineh à l'époque ramesside. Bibliothèque d'Etude 96. Cairo: Institut français d'archéologie orientale, 1985. 
Vandier d'Abbadie, Jeanne. "Deux ostraca figurés". Bulletin de l'Institut Française d'Archéologie Orientale 56 (1957): 21-34.

Vittmann, Günter. "Beobachtungen und Überlegungen zu Fremden und Hellenisierten Ägyptern im Dienste einheimischer Kulte". Pages 1231-250 in Egyptian Religion, The Last Thousand Years: Studies Dedicated to the Memory of Jan Quagebeur, Part II. Orientalia Lovaniensia Analecta 85. Edited by W. Clarysse, A. Schoors and H. Willems. Leuven: Peeters, 1998.

Vos, Rene L. The Apis Embalming Ritual: P. Vindob. 3873 . Orientalia Lovaniensia Analecta 5o. Leuven: Peeters, 1993.

Weinfeld, Moshe. "Instructions for Temple Visitors in the Bible and in Ancient Egypt". Pages 224-50 in Egyptological Studies. Scripta Hierosolymitana 28. Edited by S. IsraelitGroll. Jerusalem: Magnes Press, 1982.

Wildung, Dietrich. Ägypten 2000 v. Chr. Die Geburt des Individuums. Munich: Hirmer, 2000.

Wilfong, Terry G. “Menstrual Synchrony and the 'Place of Women' in Ancient Egypt (OIM 13512)". Pages 419-34 in Gold of Praise: Studies on Ancient Egypt in Honor of Edward F. Wente. Studies in Ancient Oriental Civilizations 58 . Edited by E. Teeter and J. A. Larson. Chicago: University of Chicago Press, 1999.

Willems, Harco. "The Embalmer Embalmed: Remarks on the Meaning of the Decoration of Some Middle Kingdom Coffins". Pages 343-72 in Essays on Ancient Egypt in Honour of Herman te Velde. Egyptological Memoirs 1. Edited by Jacobus van Dijk. Groningen: Styx, 1997.

Žabkar, Louis V. Hymns to Isis in Her Temple at Philae. Hanover: University Press of New England, 1988.

Zauzich, Karl-Theodor. Die Ägyptische Schreibertradition in Aufbau, Sprache und Schrift der Demotischen Kaufverträge aus Ptolemäischer Zeit. Ägyptologische Abhandlungen 19. Wiesbaden: Harrassowitz, 1968. 